\title{
THE GENUS ILEX IN CHINA, II
}

\author{
SHIU-YING HU
}

Continued from page 344

\section{Section VII. AQUifolium Gray}

Ilex $\S$ Aquifolium Gray, Man. Bot. N. U. S. 276. 1848; Maxim. in Mém. Acad. Sci. St. Pétersb. VII. 29(3) : 26. 1881; Rehd. Bibliog. Cult. Trees Shrubs 399. 1949.

Ilex subgen. Euilex Loes. series C. Aquifolium (Maxim.) Loes. in Verh.

Bot. Ver. Brand. 33: 26. 1891, in Engler \& Prantl, Nat. Pflanzenfam.

Nachtr. 219. 1897, et in Nov. Act. Acad. Caes. Leop.-Carol. Nat. Cur. 78: 227 (Monog. Aquif. 1: 227). 1901.

Evergreen trees or shrubs with fasciculate inflorescences in the axil of the leaves of the second year's or even older growth, the pyrenes 4, rarely less, with stony or woody striate and sulcate or rugose and pitted endocarps.

Forty-seven species in five series occur in China. Most of the species are locally endemic. The range of the five series is as illustrated in figure 8.

\section{KEy TO THE SERIES}

A. Leaves spinose or entire with the apex ending in a spine (except Ilex hylonoma).

B. Pyrenes stony, irregularly wrinkled and pitted; fruit always containing 4 pyrenes....................... Aquifolios 1.

BB. Pyrenes woody, palmately striate; fruit containing 2 pyrenes.... ............................... Deries 2. Dipyrenae.

AA. Leaves entire, serrate or crenate, those from the mature plant never spinose.

B. Pyrenes irregularly wrinkled and pitted, the endocarp stony; fruit $8-12 \mathrm{~mm}$. in diameter; stigma navel-like, rarely discoid........ Series 3. Denticulatae.

BB. Pyrenes palmately striate and sulcate; fruit 4-6 rarely up to $8 \mathrm{~mm}$. in diameter; stigma discoid, capitate, rarely navel-like.

C. Leaves chartaceous or subcoriaceous, when dry brunneous, with impressed veinlets on the upper surfaces; fruiting pedicels 4-7 mm. long.............. Series 4. Hookerianae.

CC. Leaves thick coriaceous, coriaceous, rarely subcoriaceous, the veinlets obscure or plane above, never impressed; fruiting pedicels $2-4 \mathrm{~mm}$. long................ Reries 5 . Repandae. 
Series 1. AQUifolioideS (Loes.), stat. nov.

Ile.x subgen. III. Euilex Loes. ser. C. Aquifolium (Gray) Loes. sect. 2. Aquifolioides Loes. in Engler \& Prantl, Nat. Pflanzenfam. Nachtr. 219. 1897, et in Nov. Act. Acad. Caes. Leop.-Carol. Nat. Cur. 78: 244 (Monog. Aquif. 1: 244). 1901.

Trees or shrubs with spinose or coarsely serrate leaves, fasciculate inflorescences, the individual branches of the staminate fascicles 1-3flowered, those of the pistillate fascicles uniflorous, the flowers 4-merous, the fruiting pedicels $2-12 \mathrm{~mm}$. long, the fruit large, $6-12 \mathrm{~mm}$. in diameter, the pyrenes wrinkled and pitted, the dorsal surfaces convex, and the endocarp stony.

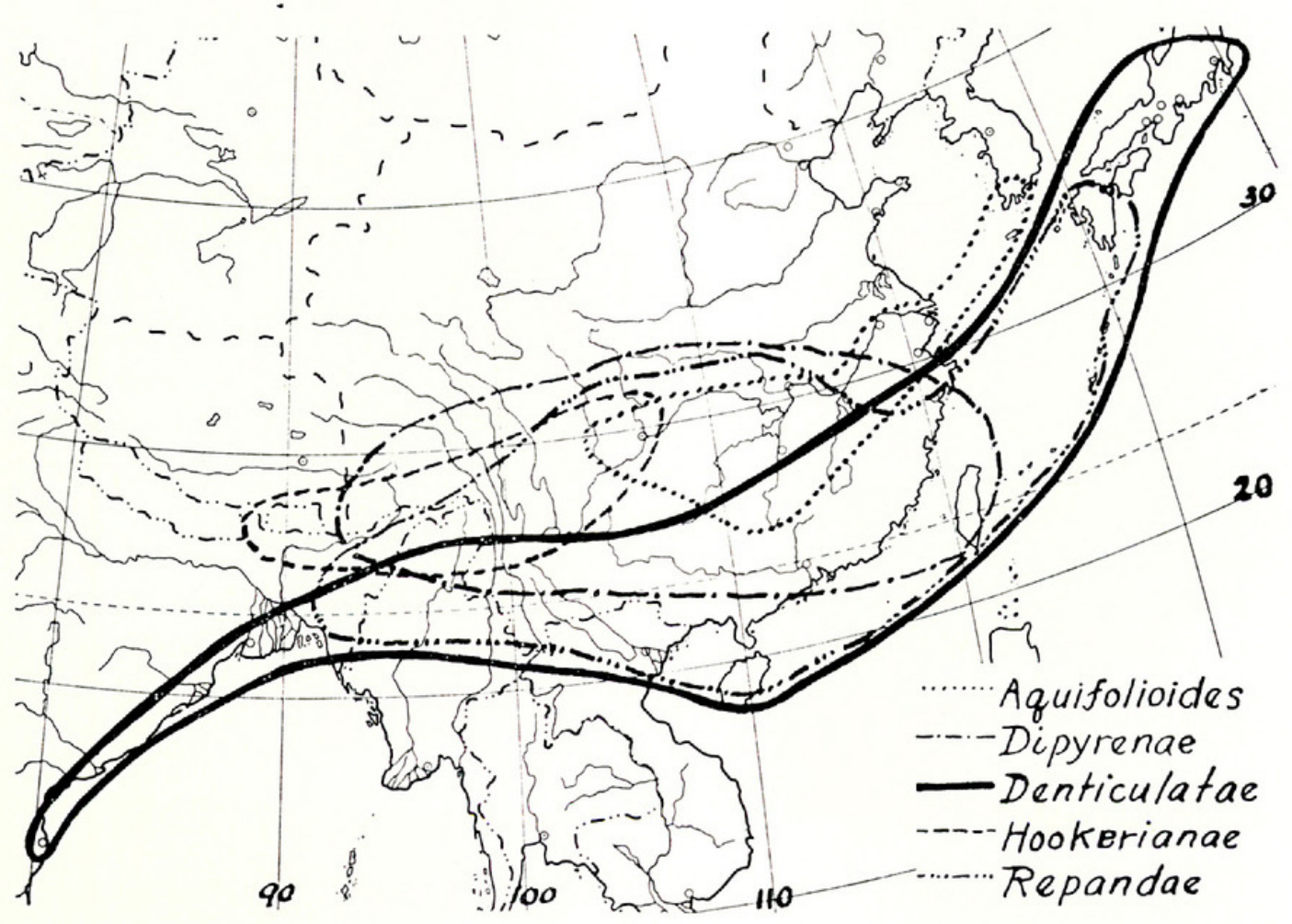

FIG. 8. Geographic distribution of the Chinese representatives of the five series of the section Aquifolium.

\section{Key to the Species}

A. Fruiting pedicels $2 \mathrm{~mm}$. long; leaves oblong-elliptic or elliptic-lanceolate, the margin spinosely dentate or coarsely serrate.

B. Individual branches of the staminate fascicles 3-flowered; leaves 6-12.5 cm. long, $2.4-4.5 \mathrm{~cm}$. wide, the margin coarsely serrate, sometimes the teeth ending in weak spines; fruit $10-12 \mathrm{~mm}$. in diameter with a discoid or mammiform stigma. (Szechuan, Kweichow, and Kwangsi).................. I. hylonoma.

$B B$. Individual branches of the staminate fascicles uniflorous; leaves 6-7 cm. long, 1.5-2.8 cm. wide, the margin 4-10 spinose-dentate; fruit 6-7 mm. in diameter, with a thin-discoid stigma. (HupeiSzechuan border $) \ldots \ldots \ldots \ldots \ldots \ldots \ldots . \ldots \ldots$ I. centrochinensis. 
AA. Fruiting pedicels 5-18 mm. long; leaves quadrangular-oblong, rarely ovate, the margin entire or sinuate with $1-3$ rigid spines on each side. (East and Central China) ..................... I. cormuta.

37. Ilex hylonoma Hu \& Tang in Bull. Fan. Mem. Inst. Biol. Bot. 9: 250. 1940.

Ilex intermedia sensu S. Y. Hu in Ic. Pl. Omei. 2: pl. 164. 1946, non Loes.

An evergreen tree up to $10 \mathrm{~m}$. high with glabrescent or glabrous branchlets, elliptic or oblong-elliptic, coarsely and sharply serrate, slightly acuminate leaves, large $(10-12 \mathrm{~mm}$. in diameter) ellipsoid fruits, and 4 large (7-9 mm. long) bony wrinkled and pitted pyrenes, each with a median longitudinal ridge.

Branchlets straight, castaneous; second year's growth subterete, $3 \mathrm{~mm}$. in diameter, plicate; current year's growth $2 \mathrm{~mm}$. in diameter, slightly angular, striate and sulcate, the terminal buds slender, acute, conic, glabrous, with ciliate bud-scales. Leaves occurring also on second year's growth (3-)25(-37) mm. apart; stipules minute, deltoid, $1 \mathrm{~mm}$. long, acute; petiole 8-14 mm. long, one-eleventh to one-seventh the length of the lamina, canaliculate and minutely puberulent above, rugose beneath; lamina thin-coriaceous, elliptic or oblong-elliptic, 6-12.5 cm. long, 2.4-4.5 $\mathrm{cm}$. wide, acute or obtuse, rarely cuneate at the base, shortly acuminate at the apex, the very tip mucronate; margin coarsely and sharply serrate, sometimes the teeth ending in weak spines; the midrib impressed above, pilose or glabrescent above, elevated and prominent beneath, the lateral nerves 9 pairs, obscurely impressed above, elevated and prominent beneath, branched and anastomosing near the margin, the reticulations of the veinlets evident above, rather obscure beneath. Inflorescences fasciculate, axillary on second year's growth, the bracts deltoid, acute, glabrous and ciliate; flowers 4-merous. Staminate inflorescences: individual branches of the fascicle 3 -flowered, sparsely puberulent; peduncles $1 \mathrm{~mm}$. long, the pedicel $3 \mathrm{~mm}$. long, with 2 ciliate basal prophylla; calyx patelliform, $1.8 \mathrm{~mm}$. in diameter, glabrous, the lobes broadly deltoid, obtuse, ciliate, $0.5 \mathrm{~mm}$. long, $0.5-1 \mathrm{~mm}$. wide; corolla rotate, the petals obovateelliptic, 3.3-3.5 mm. long, $1.8 \mathrm{~mm}$. wide, one-eighth connate at the base; stamens slightly longer than the petals, the anthers ovoid; rudimentary ovary subglobose. Pistillate flower not seen. Infructescences paucifasciculate, the pedicels $2 \mathrm{~mm}$. long, with 2 sub-basal prophylla. Fruit ellipsoidsubglobose, $10-12 \mathrm{~mm}$. in diameter, quite wrinkled when dry, the persistent calyx explanate, $3 \mathrm{~mm}$. across, the stigma prominent, thickly discoid or almost mammiform. Pyrenes 4, obovate in outline, trigonous in crosssection, the apical end obliquely retuse, 7-9 $\mathrm{mm}$. long, 3-4 mm. wide, the dorsal surface irregularly wrinkled and pitted, with a median longitudinal ridge, the endocarp bony.

CHINA: Szechuan: Mt. Omei, H. C. Chow 11831 (A); W. P. Fang $12579(\mathrm{~A}, \mathrm{Sz}), 14971(\mathrm{Sz}), 15296(\mathrm{Sz}), 15517(\mathrm{Sz}), 16496(\mathrm{Sz}), 18229$ $(\mathrm{Sz}), 18540(\mathrm{Sz})$; S. N. Hsu 678 (SS): T. C. Lee $3710(\mathrm{Sz}), 4438(\mathrm{Sz})$; W. W. Ma $2691(\mathrm{Sz}), 2339(\mathrm{Sz}), 2762(\mathrm{Sz}), 2771(\mathrm{Sz})$; G. L. Sun 135 
(Sz), 149 (Sz) ; T. H. Tu 397 (Isotype, SS) ; without precise locality, C. $W$. Yao 3659 (SS). K we ichow: Wong-Mou, Chen-feng, S. W. Tseng 90969 (A), $90969 B$ (A).

Ilex hylonoma was first reported from Mount Omei, the sacred mountain in West China. There it grows as a small tree 3-4 m. high in thickets at altitudes of $950-1200 \mathrm{~m}$., or as a big tree $10 \mathrm{~m}$. high in mixed forests at altitudes of 1300-1700 m. Its yellowish flowers appear in March. The large fruits become brown in October and red in November (ex Fang).

Ilex hylonoma is closely related to Ilex centrochinensis. In the thincoriaceous texture of the leaves, the fasciculate inflorescences, the very shortly pedicellate fruits, and in the sculpturing of the pyrenes, they are almost alike. They differ in that Ilex centrochinensis has smaller spinose leaves, uniflorous branches of the staminate fascicles, and smaller pyrenes.

37a. Ilex hylonoma var. glabra, var. nov.

Arbor glabra; foliis coriaceis vel crasse coriaceis, lanceolatis, oblanceolatis, ovato-lanceolatis vel ellipticis, $6-10 \mathrm{~cm}$. longis, $1.8-4.2 \mathrm{~cm}$. latis, margine serratis vel tenuiter spinosis; fructibus ellipsoideis vel subglobosis, 8-10 $\mathrm{mm}$. diametro, pedicellis $2-3 \mathrm{~mm}$. longis; pyrenis 4 , oblongis, trigonis, apice oblique retusis, $6-8 \mathrm{~mm}$. longis, endocarpio lapideo.

Branchlets, terminal buds, pedicels, midrib and petioles all glabrous; leaves coriaceous or thickly coriaceous, lanceolate, oblanceolate, ovatelanceolate or elliptic, $6-10 \mathrm{~cm}$. long, $1.8-4.2 \mathrm{~cm}$. wide, coarsely serrate or weakly spinose; fruits ellipsoid or subglobose, $8-10 \mathrm{~mm}$. in diameter; pedicels 2-3 mm. long, prophylla 2, median, ciliate; pyrenes 4, oblongtrigonous in outline, $6-8 \mathrm{~mm}$. long, with 1 median longitudinal ridge along the back, the apical end obliquely retuse, the endocarp bony.

CHINA: Chekiang: Chu-an-hsien, Y. L. Keng 726 (A). H un an : Chang-sa, Handel-Mazzetti 11501 (A, LU). K w a ng si : Hu-chen, R. C. Ching 5386 (NY) ; Ling-wun, S. K. Lau 28662 (A) ; Kwei-lin, W. T. Tsang 27796 (түре, A; US), 27998 (A, US), 28063 (A, US); Hing-on, Z. S. Chung (T. S. Tsoong) 83691.

Geographically this variety ranges over a wider area than does the typical West China species. It extends from the coastal provinces, Chekiang, westward to the Great Lake Province, Hunan, and southward to Kwangsi. It is a large tree $10 \mathrm{~m}$. high.

This variety differs from the typical West China species in having glabrous branchlets and midrib. The leaves are thicker in texture.

38. Ilex centrochinensis, nom. nov.

Ilex aquifolium L. var. chinensis Loes. ex Diels in Bot. Jahrb. 29: 435. 1900, nom. nud., in Nov. Act. Acad. Caes. Leop.-Carol. Nat. Cur. 78: 236 (Monog. Aquif. 1: 236). 1901, descr., et in Sarg. Pl. Wils. 1: 78. 1913; Hand.-Mzt. Symb. Sin. 7: 655. 1933; Chen, Ill. Man. Chin. Trees 658. 1937.

Ilex aquifolium sensu Franch. in Bull. Soc. Bot. France 33: 453. 1886; sensu Hemsl. in Gard. \& Forest 2: 124. 1889, non L.

Ilex dipyrena Wall. var. leptacantha Loes. 11.cc. 436. 1900, nom. nud., 278. 1901, descr. Syn. nov. 
An evergreen shrub up to $3 \mathrm{~m}$. high, with slender angular and ridged sparsely puberulent or glabrescent branchlets, lanceolate spinose leaves, fasciculate inflorescences, short-pedicellate fruits, and 4 wrinkled-pitted and median longitudinally ridged pyrenes.

Branchlets slender, longitudinally ridged and rugose, brown or nigrescent; third year's growth $3 \mathrm{~mm}$. in diameter, the lenticels lacking, the leaf-scars deltoid; second year's growth $2-2.5 \mathrm{~mm}$. in diameter, ridged; current year's growth angular, $1.5 \mathrm{~mm}$. in diameter, puberulent or glabrescent, sharply ridged from the stipules downward, the terminal buds thin, acute-conic, puberulent or glabrescent with ciliate bud-scales. Leaves occurring also on the second year's growth, 5-15 mm. apart; stipules deltoid or obliquely deltoid; petioles $5-8 \mathrm{~mm}$. long, one-eleventh to one-ninth the length of the lamina, very shallowly impressed above; lamina coriaceous, brown, shiny above, less so beneath, elliptic-lanceolate, rarely ovate-elliptic, $5-9$ (usually $6-7$ ) $\mathrm{cm}$. long; $1.5-2.8 \mathrm{~cm}$. wide; obtuse or rarely rounded at the base; acuminate at the apex, the acumen deltoid, 6-12 mm. long, terminating in a spine; margin spinose-dentate, the spines 4-10 on each side, 2-4 mm. long, the tips nigrescent; midrib shallowly impressed above, puberulent near the base, elevated beneath, the lateral nerves 6-8 pairs, obscure, rarely evident above, obscure or rarely prominent beneath. Inflorescences fasciculate, axillary on the second year's growth; the bud-scars often persistent, broadly ovate, cartilaginous, puberulent or glabrescent, the individual branches of the fascicles uniflowered, the bracts ovate-lanceolate, pubescent, ciliate; flowers 4-merous. Staminate flowers: pedicels 1-2 mm. long, puberulent, with 2 median ciliate prophylla reaching the calyx; calyx patelliform, $2.5 \mathrm{~mm}$. across, deeply lobed, the lobes ovate, deltoid, ciliate and often puberulent; corolla rotate, $6 \mathrm{~mm}$. across, the petals oblong, $3 \mathrm{~mm}$. long, the distal half ciliate, one-eighth connate at the base; stamens longer than the petals, the anthers oblong-ovate; rudimentary ovary subglobose, the apex rounded. Pistillate flower not known. Infructescences paucifasciculate, the fascicles with 1-3 fruits, the pedicels $2 \mathrm{~mm}$. long, puberulent, with 2 sub-basal ciliate prophylla; persistent calyx explanate, quadrangular in outline, $2 \mathrm{~mm}$. across, the lobes ciliate. Fruit globose, 6-7 mm. in diameter, the stigma thin-discoid, 4-lobed. Pyrenes 4, oblong-trigonous in outline, ca. $6 \mathrm{~mm}$. long, $3 \mathrm{~mm}$. wide at the back, wrinkled and pitted all over, the dorsal surfaces with a median longitudinal ridge, the ends obtuse, the endocarp stony.

CHINA: Hupei (Hupeh): Chien-shih-hsien, H. C. Chow 1523 (A, NY) ; Nan-yang-ho, western Hupei, $W . Y$. Chun 3857 (A); Ichang, $A$. Henry 1084 (TyPE, fruit, G), 3299 (A, G, US) ; 4239 (TyPE of Ilex dipyrena var. leptacantha, A) ; E. H. Wilson 108 (A, NY), 295 B (A), 3100 (A, US). Szechuan : E. Faber 87 (NY); Wu-shan-hsien, E. H. Wilson 1028 (A); W. Y. Chun 4098 (A).

This species is endemic to the Hupei-Szechuan border where the Yangtze River cuts through the limestone mountains forming the famous huge deep gorges. It is in this area that Metasequoia has recently been dis- 
covered. There Ilex centrochinensis grows as a shrub along the roadside, margin of the woods or by small streams at altitudes of 500-700 m. The flowers appear in March and April, and the fruit turns purplish red in middle August (ex Chun) or is still green in September (ex Chow).

In indumentum and leaf characters, Ilex centrochinensis is most closely allied with Ilex aquifolium Linn., but the latter has 3-flowered branches in the staminate inflorescences, fruiting pedicels as long as or longer than the diameter of the mature fruits, reticulately striate and sulcate pyrenes which lack a distinct median longitudinal ridge on the back. Moreover, Ilex aquifolium Linn. does not occur in any part of China unless cultivated. In the color and texture of the dry leaves, the nature of the inflorescences, the short fruiting pedicels, and in the character of the pyrenes, Ilex centrochinensis is very closely related to Ilex hylonoma $\mathrm{Hu}$ and Tang, but the latter has larger (up to $12 \mathrm{~cm}$. $\times 4 \mathrm{~cm}$.) serrate leaves, and much larger fruits (up to $12 \mathrm{~mm}$. in diameter).

Loesener with the specimen A. Henry 4239 created the variety Ilex dipyrena Wall. var. leptacantha, basing it upon Ilex leptacantha Lindl. \& Paxt. But the specimen he examined does not belong to the species as he supposed. It is a fruiting specimen. Each fruit has 4 stony, wrinkledpitted, longitudinally ridged pyrenes which are typical of Ilex centrochinensis. It is apparently a branch from a vigorously growing plant. The leaves are larger and thinner, and the lateral nerves are more evident above than in the other Henry specimens. But this variation is very common in any growing shrub.

39. Ilex cornuta Lindl. \& Paxt. Flow. Gard. 1: 43, fig. 27. 1850, in Gard. Chron. 1850: 311. 1850; Loud. Encyc. Pl. Suppl. 2: 1302. 1855; Hook. in Bot. Mag. 14: pl. 5059. 1858; Moore in Jour. Bot. 16: 137. 1878; Maxim. in Mém. Acad. Sci. St. Pétersb. VII, 29(3) : 44. 1881; Forbes \& Hemsl. in Jour. Linn. Soc. Bot. 23: 115. 1886; Loes. ex Diels in Bot. Jahrb. 29: 436. 1900, in Nov. Act. Acad. Caes. Leop.-Carol. 78: 280 (Monog. Aquif. 1: 280). 1901, et in Sarg. Pl. Wils. 1: 78. 1911; Schneid. Ill. Hand. Laubh. 2: 164. 1912; H. Lévl. in Mém. Real Acad. Cien. y Art. 12: 13. 1916; Gee in Sci. [China] 6: 212. 1921; Chung in Mem. Sci. Soc. China 1: 139. 1924; Liu in Bull. Pek. Soc. Nat. Hist. 2: 126. 1928; Belval, Mus. Heude Not. Bot. Chin. 2: 21. 1933; Hand.-Mzt. Symb. Sin. 7: 656. 1933; Cheng in Contr. Biol. Lab. Sci. Soc. China 9: 171. 1934; Chen, Ill. Man. Chin. Trees 657. 1937.

Ilex cornuta forma typica Loes. op. cit. 281. 1901. Syn. nov.

Ilex cornuta forma gaëtana Loes. 1.c. Syn. nov.

Ilex furcata Lindl. in hortis: Göppert in Gartenfl. 1853: 322. 1854.

Ilex burfordii S. R. Howell, Descr. Cat. Howell Nurs. 19. 1935, nom. nud. Ilex cormuta var. burfordii De France in Nat. Hort. Mag. 13: 193. 1934; Clarke in Jour. Hort. Soc. 6: 284. 1945.

Ilex cornuta forma burfordii (De France) Rehd. in Bibl. Cult. Trees Shrubs 400. 1949. Syn. now. 
An evergreen shrub or small tree with firm thick-coriaceous dimorphic leaves varying from cordate or oblong-entire to quadrangular and sinuatespinose, fasciculate inflorescences, globose drupes, and 4 wrinkled-pitted stony pyrenes, entirely or half-grooved along the dorsal longitudinal line.

Branchlets stout, subterete, cinereous when dry; third year's growth $5 \mathrm{~mm}$. in diameter, longitudinally minutely rimulose, the nodes prominent with elevated leaf-scars, the lenticels lacking; second year's growth $4 \mathrm{~mm}$. in diameter, ochraceous or brown; longitudinally striate-rugose; current year's growth 2-3 mm. long, longitudinally ridged, minutely puberulent in the grooves or glabrescent, the terminal bud small, thin-conical, puberulent or glabrescent. Leaves occurring even on the third year's growth, 5-10 mm. apart; stipules broadly deltoid, callose, ca. $0.4 \mathrm{~mm}$. long, 0.5 $\mathrm{mm}$. wide; petioles $4-8 \mathrm{~mm}$. long, one-seventeenth to one-ninth the length of the lamina, puberulent, narrowly impressed above; lamina thickcoriaceous, olivaceous, shiny above, opaque beneath, quadrangular-oblong, rarely ovate, (3-)5-6(-8) $\mathrm{cm}$. long, (2-)2.5-3(-4) $\mathrm{cm}$. wide; round or truncate at the base; acute or shortly acuminate at the apex, the very tip always terminating in a strong spine; margin entire or sinuate with 1-3 spines on each side, rigid, thickened and of lighter color than the lamina; midrib very slightly impressed (almost plane on the distal half) above, prominent and elevated beneath, the lateral nerves 5 or 6 pairs, anastomosing near the margin, obscure above, evident beneath, the reticulation of the veinlets obscure on both surfaces. Inflorescences fasciculate, sessile, axillary, on second year's growth, the persistent scales suborbicular, cartilaginous, ciliate and sparsely puberulent, $1.5 \mathrm{~mm}$. long, the individual branches of the fascicles uniflowered, the bracts ovate, pubescent, ciliate, obtuse or mucronate, with 2 subulate basal appendages; flowers 4-merous. Staminate inflorescences: pedicels 5-6 mm. long, glabrous, with 1 or 2 sub-basal minute broadly deltoid prophylla; calyx patelliform, $2.5 \mathrm{~mm}$. across, the lobes membranaceous, broadly deltoid, sparsely puberulent, ciliate, $0.75 \mathrm{~mm}$. long, $1.5 \mathrm{~mm}$. wide; corolla rotate, $7 \mathrm{~mm}$. across, the petals oblong-ovate, $3.5 \mathrm{~mm}$. long, with the apical ends very sparsely ciliate, one-tenth connate at the base; stamens subequaling or slightly longer than the petals, the anthers ovoid-oblong, $1 \mathrm{~mm}$. long; rudimentary ovary subglobose, the apex obtuse or rounded, indistinctly 4-lobed. Pistillate inflorescences: pedicels 8-9 mm. long, glabrous, after fruiting 13-14 mm. long with minute broad deltoid basal prophylla; calyx patelliform, the lobes obtuse, sparsely puberulent and ciliate; corolla rotate, $7 \mathrm{mr}_{\text {. }}$. across, choripetalous, the petals oblong-ovate, $3.5 \mathrm{~mm}$. long, sparsely ciliate; staminodes four-fifths the length of the petals, slightly longer than the ovary, the sterile anthers ovate-sagittate; ovary oblong-ovoid, 3-4 mm. long, $2 \mathrm{~mm}$. wide, the stigma discoid. Fruit globose (ellipsoid before reaching maturity), $8-10 \mathrm{~mm}$. in diameter, the persistent calyx quadrangular in outline, the stigma discoid, distinctly 4-lobed. Pyrenes 4, obovate or elliptic in outline, the ends acute, $7-8 \mathrm{~mm}$. long, $5 \mathrm{~mm}$. wide at the back, wrinkled-pitted, rugose all over, the dorsal surface entirely 
or partly canaliculate along the median longitudinal line, the endocarp bony.

CHINA: Kiangsu: Nanking, Chen \& Teng 3960 (A, US), 3961 (NY); W. C. Cheng 383 (SS); W. P. Fang 10416 (SS), 61108 (SS). S oochow: H. F. Feng in 1925 (G); Y. L. Keng 1692 (A, NY); E. Faber (NY); Chiu-yong, K. King 2175 (G); A. N. Steward (ex Herb. Univ. Nanking 1959) (A), 7261 (NY, US); Y. Z. Sun 1067 (SS); Tso 28 and 210 (A). Chekiang: Moh-kan-san, S. P. Barchet (US); Tienmu-shan, $W$. C. Cheng 3624 (US); Tih-tai-shan, R. C. Ching 1374 (A, US) ; Hangchow, C. Y. Chiao (ex Herb. Univ. Nanking 7966) (US); Nin-po, C. K. Chao in 1935, (CUB) ; S. S. Liu in 1935 (CUB); Tsing-yunhsien, Y. L. Keng 449 (A, SS); Chang-hwa-hsien, Y. L. Keng 574 (A); Chun-an-hsien, Y. L. Keng 712 (A); Lin-an-hsien, H. H. Hu 1562 (A); locality not given, D. Macgregor in 1908 (A); Tang-si, F. H. Meyer 229 (A) ; Tien-mo-shan, T. Tang $\mathcal{E} W . Y$. Hsia 428 (A). An hw e i : Hwangshan, S. S. Chien 1336 (SS); Bau-hua-shan, W. C. Cheng 434 (SS, US), 5897 (SS); C. Pei 2439 (SS). K i angsi: Nan-chang, H. H. Chung 658 (LU) ; J. N. Hsiung 504 (A); Kian, F. A. McClure 3421 (LU); Kao-ping, Y. Tsiang 9893 (NY); Kiu-kiang, E. H. Wilson 1608 (A, SS). H u pei (Hupeh): Wu-chang, S. C. Sun 1078 (A, NY); Ichang, A. Henry $3292 A$ (G); E. H. Wilson $3101 A$ (A, US). H un an: Tsing-tschou (Chang-sa), Handel-Mazzetti 364, 637, 442 (A).

KOREA: Senra, Taquet 2721 (A); same province, E. H. Wilson 11242 (A).

CULTIVATED: I have seen specimens from the gardens of Kew, England, Hannover and Dahlem, Germany, Locarno, Switzerland, and from gardens and nurseries of Virginia, Tennessee, and Georgia in the United States.

Ilex cornuta is endemic to the hilly regions of the lower Yangtze provinces from the sea up to western Hupei. There its yellow flowers appear in April and the fruit turns red in November.

Ilex cornuta was first introduced to England from the vicinity of Shanghai by R. Fortune in 1846. The first published record of it appeared in 1850. From the very beginning Lindley and Paxton had clearly stated the variation in leaf forms, "Foliis . . . in plantâ vegetiore grossè sinuatodentatis spinosis in adultâ 3-cornibus integrisque." In 1908 Dallimore commented on Fortune's specimen deposited in Kew, saying, "it appears that the upper leaves on mature trees vary in shape, sometimes being spineless and sometimes bearing but one or two spines." This is correct.

Ilex cornuta is like many other Asiatic spinose species of Ilex in that maturity in the plant and aridity in the environment are associated with the reduction of the number of spines on the leaves, often even with entire leaves. Such a dimorphism in leaves is very common with wild Ilex cornuta. It has been reported from Chekiang by Keng, from Anhwei by Ching, and in Nanking I have personally seen trees about $5 \mathrm{~m}$. high with some branches bearing entire leaves and others bearing spinose leaves. The type or parent plant of Ilex cornuta var. burfordii De France in the West View Cemetery, Atlanta, Georgia, must have been propagated 
from such an entire-leaved shoot. De France admitted, "When seeds of Ilex cornuta var. Burfordii germinate they produce seedlings similar to Ilex cornuta ..." Therefore, his variety may be considered as a horticultural clone, but not a taxonomic form or variety.

The branchlets of Ilex cornuta are rather flexible. In China they are used by farmers to make nose-rings for cattle. The bark and the leafy shoots are used as medicine. The plant is believed to be an excellent remedy for diseases of the kidney and is commonly administered as a tonic. It is also widely cultivated as an ornamental shrub.

39a. Ilex cornuta var. fortunei (Lindl.), comb. nov.

Ilex fortunei Lindl. in Gard. Chron. 1857: 868. 1857; Chung in Mem. Sci. Soc. China 1: 140. 1924.

Ilex cormuta sensu Rehd. in Jour. Arnold Arb. 8: 156. 1927, pro parte.

Branchlets minutely puberulent or glabrescent; leaves thick-coriaceous, oblong, obovate-oblong, or quadrangular, the margin entire, occasionally with 2 or 3 strong spines on each side, rigidly thickened; inflorescences fasciculate or in the staminate inflorescence pseudopaniculate with a rachis up to $10 \mathrm{~mm}$. long; individual branches of the staminate fascicles 1-3flowered, the pedicels 5-15 mm. long, when 3-flowered the peduncles 1-2 mm. long; individual branches of the pistillate fascicles uniflorous, the pedicels $12 \mathrm{~mm}$. long, after fruiting up to $18 \mathrm{~mm}$. long; fruit globose, 10-11 mm. in diameter, the stigma plane-discoid or almost capitate.

CHINA: Ki angsu: Nanking, E. D. Merrill 11371 (A). Hon an : Ki-Kiang-shan, A. N. Steward 5239 (US), 9838 (A, US). A n hw ei : Chu-swha-shan, R. C. Ching 2719 (A, LU) ; Liu-chu-wan, R. C. Ching 2736 (A, US) ; Chien-shan-hsien, C. S. Fan \& Y. Y. Li 72 (A). Chekiang : Tung-yang-hsien, Y. L. Keng 912 (A). H u pe i : Ichang, A. Henry 3292 (A, G, US) ; E. H. Wilson 3101 (A, SS); without precise locality, F. B. Forbes 854 (A).

Wilson 3101 is a mixture of staminate flowers and young fruits. The former have long pedicels, often with 3 -flowered branches. The latter have short pedicels. In the Arnold Arboretum, I have numbered the latter $3101 \mathrm{~A}$.

Cultivated: I have seen specimens collected from La Mortola, Italy, by A. Rehder and also by C. Schneider; from United States National Botanic Gardens by P. Russell, and from Australia by J. F. Bailey.

Geographically, there is no clear demarcation between this variety and the typical Ilex cornuta. However, so far as is known, the variety has not been reported in those coastal areas beyond Long. $120^{\circ} \mathrm{E}$. It commonly occurs in the hilly high lands on both sides of the Yangtze River from Kiangsu west to Hupei. The flowers appear in April and the fruit becomes red in November, persisting for a long time on the branches.

This variety differs from typical Ilex cornuta in having 3-flowered branches of the staminate inflorescences and longer fruiting pedicels (12-18 mm.). It was first collected by Fortune in Hwuy-chow, S. Anhwei. 
His specimen was from an old plant with entire leaves. About it Lindley wrote, "In its young state it is much like $I$. cornuta, but in the adult condition it acquires quite another appearance, resembling a very broad-leaved entire-leaved European Holly . . . in the axil of each leaf a sessile umbel of from 6-10 stalks [of fruits] each about three-quarters of an inch long . .." In S. Anhwei it was again collected by $R$. C. Ching (2719 with entire leaves only and 2736 with both entire and spinose leaves). Merrill's specimen from Purple Mountain in Nanking and Henry's and Wilson's specimens from western Hupei both possess spinose leaves only. It is obvious that in nature leaf dimorphism is as common in this long-pedicellate variety as in the typical Ilex cornuta.

\section{Series 2. DipyrEnAE, ser. nov.}

Arbor vel frutex, ramulis puberulis; foliis coriaceis, rigidis, juvenilibus spinosis, in maturitate interdum partim integris; inflorescentiis paucifasciculatis, fasciculis 1-5-floris; fructus pedicellis $1-3 \mathrm{~mm}$. longis; fructibus ellipsoideis vel depresso-globosis, saepe in paribus; pyrenis 1-4, plerumque 2, palmatim striatis et sulcatis, endocarpio crasso, lignescente.

\section{Key to the Species}

A. Trees; leaves comparatively large, 6-9 cm. long, often entire; petioles 4-5 mm. long. (India-Yunnan) ............... I. dipl'rena.

AA. Shrubs; leaves $2-4.5 \mathrm{~cm}$. long; petioles less than $3 \mathrm{~mm}$. long.

B. Pyrenes 4 ; leaves ovate.

C. Leaves 3-4.8 cm. long, the margin sinuate, with 3-7 spines on each side; pyrenes suborbicular in outline, $4.5 \mathrm{~mm}$. wide, broadly grooved on the dorsal surface. (Chekiang) .........

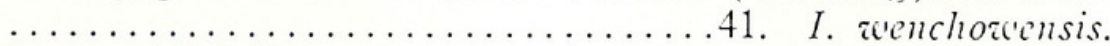

CC. Leaves 1.3--2.5, rarely up to $3 \mathrm{~cm}$. long, the margin with 1 or 2 , rarely 3 spines; pyrenes obovate or oblong, less than $4 \mathrm{~mm}$. wide, impressed only at the broader end. (West and northwest China) ................. I. pernyi.

BB. Pyrenes usually 2, rarely 1 ; leaves lanceolate, elliptic, rhomboid, quadrangular, rarely ovate, usually over $4 \mathrm{~cm}$. long (except $I$. perryana).

C. Leaves lanceolate, with numerous, spines; fruit obovoid-ellipsoid, 5-6 mm. in diameter. (Yunnan)......43. I. georgci.

CC. Leaves elliptic, rhomboid, or quadrangular, rarely ovate; fruit ellipsoid or subglobose, $8-10 \mathrm{~mm}$. in diameter.

D. Erect shrubs over $1 \mathrm{~m}$. high: leaves elliptic or ovate, truncate or rounded at the base, acuminate at the apex: the veinlets indistinct above; pyrenes 2 , palmately striate and sulcate.

E. Leaves elliptic or ovate; margin with 4-6 weak spines on each side; pedicels of fruits pubescent. (Szechuan) ............... I. ciliospinosa.

EE. Leaves ovate or quadrangular, margin with 2-3 strong spines on each side; pedicels of fruits glabrous. (Yunnan to Taiwan)....45. I. bioritsensis. 
DD. Prostrate shrubs less than $30 \mathrm{~cm}$. high; leaves subrhomboid, rugose, obtuse at the base, broadly deltoid and acute at the apex, the upper surface with deeply impressed veinlets; pyrene 1, palmately striate and esulcate. (Yunnan, high altitude) ...............46. I. perryana.

40. Ilex dipyrena Wall. in Roxb. Fl. Ind. ed. Carey, 1: 473. 1820; D. Don, Prod. Fl. Nep. 188. 1825; Wall. List, 4327. 1830, et Pl. As. Rar. 3: pl. 292. 1832; Walp. Rep. 1: 540. 1842; Loud. Encyc. Pl. Suppl. 2: 1302. 1855; Brandis, For. Flor. 76. 1874; Hook. f. Fl. Br. Ind. 1: 599. 1875; Franch. Pl. Delav. 127. 1889; Loes. in Nov. Act. Acad. Caes. Leop.-Carol. Nat. Cur. 78: 276 (Monog. Aquif. 1: 276). 1901; Chung in Mem. Sci. Soc. China 1: 140. 1924; Hand.-Mzt. Symb. Sin. 7: 656. 1933; Comber in Notes Bot. Gard. Edinb. 18: 44. 1933; Chen, Ill. Man. Chin. Trees 659. 1937.

Ilex dipyrena var. connexiza W. W. Sm. in Notes Bot. Gard. Edinb. 10: 41. 1917; Comber op. cit. 61. 1933. Syn. nov.

Ilex dentonii Hort. ex Loud. 1. c.

Ilex dipyrena var. paucispinosa Loes. op. cit. 89: 283. 1908; Comber op. cit. 18: 45. 1933. Syn. now.

Ilex monopyrena Watt. ex Loes. op. cit. 275. 1901; Hu and Tang in Bull. Fan Mem. Inst. Biol. Bot. 9: 252. 1940. Syn. nov.

Ilex bioritsensis Hayata var. integra Comber op. cit. 43. 1933. Syn. nov.

A puberulent evergreen tree up to $14 \mathrm{~m}$. high with coriaceous ellipticoblong, rarely ovate or lanceolate, spinose (or entire with an apical spine) leaves, fasciculate inflorescences, globose or ellipsoid fruits, 1-4 pyrenes with thick woody palmately striate and sulcate endocarp.

Branchlets straight, stout; third year's growth 4-6 mm. in diameter, cinereous, minutely longitudinally rimulose, the lenticels lacking or obscure, the leaf-scars semi-orbicular, not elevated; current year's growth subangular, longitudinally striate rugose or smooth, minutely puberulent or glabrescent, cinereous or cinnamon, the terminal buds conic, acute, puberulent. Leaves occurring also on second year's growth, 5-20 mm. apart; stipules callose, broadly deltoid, sometimes obscure; petioles 4-6 mm. long, one-twentieth to one-thirteenth the length of the lamina, shallowly canaliculate above, puberulent; lamina thick-coriaceous, shiny above or opaque on both surfaces, olivaceous, brown or even yellow, ellipticoblong or rarely ovate, $4-10 \mathrm{~cm}$. long, $2-4 \mathrm{~cm}$. wide; base rounded; apex shortly acuminate, the acumen $3-10 \mathrm{~mm}$. long, terminated by a sharp spine $2 \mathrm{~mm}$. long; margin entire or subentire with few spines or spinose with up to 14 spines on each side; midrib sulcate, puberulent or glabrescent above, elevated beneath; lateral nerves 7-9 pairs, impressed above, elevated beneath, the reticulation of the veinlets obscure. Inflorescences fasciculate, axillary on second year's growth, the individual branch of the fascicles uniflorous; the bracts ovate-lanceolate, long-ciliate, the outer ones cuspidate, the inner ones obtuse, the basal appendages subulate, flowers 2-4-merous. Staminate flowers: pedicels 2-3 $\mathrm{mm}$. long, sparsely and minutely puberulent or glabrescent, with 2 sub-basal lanceolate acute 
prophylla, $1.5 \mathrm{~mm}$. long, which reach the calyx; the calyx patelliform, 3 $\mathrm{mm}$. across, deeply lobed, the lobes membranous, ovate-deltoid, obtuse or subacute, sparsely ciliate; corolla rotate, $7 \mathrm{~mm}$. across, the petals ovate, $3 \mathrm{~mm}$. long, ciliate, one-fifth connate at the base; stamens 4, longer than the petals, the anthers oblong-ovoid, $0.75 \mathrm{~mm}$. long; the rudimentary ovary subglobose-ovoid, $1.5 \mathrm{~mm}$. in diameter, the apex truncate or obtuse. Pistillate flowers: pedicels 1-3 mm. long; calyx and corolla as in the staminate flowers; staminodes slightly shorter than the petals, the sterile anthers ovate; ovary ovoid, the stigma discoid, plane, distinctly lobed. Fruit red, globose, 6-9 $\mathrm{mm}$. in diameter, appearing subsessile, the persistent calyx explanate, quadrangular, the stigma 2-4-lobed, discoid. Pyrenes 1-4, often 2; when two, oblong-elliptic or subcircular in outline, dorso-ventrally compressed, the ends obtuse or rounded, the back convex, longitudinally and subpalmately striate and sulcate, 5-7 $\mathrm{mm}$. long, $5 \mathrm{~mm}$. wide, the ventral side also striate-sulcate; when four, oblong in outline, $3.5 \mathrm{~mm}$. wide at the back; the endocarp thick and woody.

CHINA: Yunnan: Li-kiang, R. C. Ching 20243 (A), 21576 (A); K. M. Feng 3101 (A), 3179 (A) ; J. F. Rock 3427 (A, US); C. Schneider 2845 (A) ; T. T. Yu 14921 (A) ; Hokin near Sung-kwei, K. M. Feng 6921 (A) ; western Yunnan, G. Forrest 10171 (A), 10224 (A), 10426 (A), 11071 (A), 12528 (TYPE of Ilex dipyrena var. connexiva, fragment in A), 19817 (A, US), 20096 (A, US), 20101 (A, US), 21023 (ISOTYPE of I. bioritsensis var. integra, A), 25362 (A) ; Cai-pou, E. E. Maire 125 (A); west of Ta-li, J. F. Rock 6781 (A, US); mountain of Londjre, J. F. Rock 8906 (A, US); Wei-hsi, J. F. Rock 11701 (A, US) ; locality not given, H. T. Tsai 57186 (A), 57360 (A), 57339 (A) ; Wei-si, C.W.Wang 67917 (A), 70400 (A); Atungtze, T. T. Yu 5773 (A), 7826 (A), 7831 (A), 8486 (A), 10610 (A), 11171 (A). Sikang: Zayul, Kingdon Ward 10990 (B).

INDIA: East Himalaya, Griffith 2011 (NY); Simlah, Griffith (NY); Chakrata, M. A. Hamid (NY); Ramilchet, G. Kasilingarn (NY); Punjab, W. Koelz 1990 (NY); Chamba, W. Koelz 8857 (NY); Mussoorie, R. R. Steward 14895 (NY); Kumson, R. Strachey \& J. E. Winterbottom 3 (G); Wallich 4327 (TYPE, fragments in A).

UPPER BURMA: F. K. Ward 342 (NY).

CULTIVATED: Many specimens from botanical gardens of America and Europe have been examined.

Ilex dipyrena was first described from Nepal, where it is called "caulah." According to Wallich, it "blossoms from April to July." Now, as our knowledge of the flora of southwestern China has increased, we know that it is a common and wide-spreading species in Yunnan Province, where it grows as a tree (sometimes as a shrub, after cutting by fuel-gatherers) in mixed forests, in ravines, or on slopes of mountains at an altitude of 2000-3000 m. The fruit is greenish yellow in October and red in December.

As Wallich remarked, "This species varies considerably in the shape and serratures of the leaves. Generally they are oblong and remotely serrate; sometimes, however, they are of a more ovate form, rounded at the base, the margins sinuated and marked with pretty strong unequal 
spinous serratures." This statement is true; varieties based on differences in leaf margin are not worthy of taxonomic recognition. Rock 11701 serves as a good example. On that sheet, there are subentire leaves which resemble Ilex dipyrena var. connexiva, less spinose leaves which resemble Ilex dipyrena var. paucispinosa, and very spinose leaves. In specimens collected from Yunnan, the pyrenes vary from one to four. In the double-pyrened fruits there are often one or two small globose masses of stone-cells which may indicate aborted pyrenes. The fruits of $H$. T. Tsai 57360 contain three or four pyrenes. Yet its vegetative characters show it to be an example of Ilex dipyrena.

41. Ilex wenchowensis, sp. nov.

Frutex parvus; ramulis pubescentibus, foliis spinosis, coriaceis, ovatis, $3-4.8 \mathrm{~cm}$. longis, $1.2-2.5 \mathrm{~cm}$. latis; petiolo $1-2 \mathrm{~mm}$. longo; costa supra impressa et puberulente; nervis lateralibus utrinque 4 vel 5, supra evidentibus, subtus obscuris; inflorescentiis fasciculatis, unifloribus; pedicellis 1 mm. longis, prophyllis ciliatis; calycibus 4-lobis, ciliatis; corolla rotata, 6-7 mm. diametro, petalis oblongis, $3 \mathrm{~mm}$. longis, $2.5 \mathrm{~mm}$. latis, ciliatis, one-fifth connatis; staminibus 4, quam petalos aequilongis; ovario abortu turbinato, $1 \mathrm{~mm}$. longo, apice obtuso; fructibus depresso-globosis, 5-6 mm. longis, $8 \mathrm{~mm}$. diametro, calycibus $2.5 \mathrm{~mm}$. diametro donatis; stigmate umbilicato vel discoideo; pyrenis 4 , suborbicularibus, $5 \mathrm{~mm}$. longis, 4.5 $\mathrm{mm}$. latis, dorso palmatim striatis et depressis, lateralibus striatis et sulcatis.

An evergreen shrub up to $2 \mathrm{~mm}$. high with pubescent branchlets, spinose ovate leaves, fasciculate inflorescences, depressed globose fruits and 4 palmately striate and dorsally depressed pyrenes.

Branchlets pubescent, castaneous; third year's growth $3.5 \mathrm{~mm}$. in diameter, the lenticels lacking, the leaf-scars suborbicular, not elevated; current year's growth $3 \mathrm{~mm}$. in diameter, angular and pubescent, the terminal buds narrowly conic, pubescent, unfolding after anthesis. Leaves occurring even on the third year's growth, 5-10 mm. apart; stipules minute, obscure; petioles $2 \mathrm{~mm}$. long, one-twenty-fifth to one-eighteenth the length of the lamina, puberulous; lamina coriaceous, olivaceous, slightly shiny above, ovate, $3-4.8 \mathrm{~cm}$. long, $1.2-2.5 \mathrm{~cm}$. wide, truncate or rounded at the base, acuminate and spinose at the apex; margin sinuate, with 3-7 spines on each side, the midrib slightly impressed and pubescent above, slightly elevated beneath, the lateral nerves 4-5 pairs, evident above, obscure below. Inflorescence fasciculate, axillary on second year's growth, the individual branches of the fascicles all uniflorous; flowers all 4-merous. Staminate flowers: pedicels $1 \mathrm{~mm}$. long, puberulous, with 2 large ciliate basal prophylla extending to the calyx; calyx patelliform, $2 \mathrm{~mm}$. in diameter, deeply 4-lobed, the lobes deltoid, obtuse, ciliate; corolla rotate, 6-7 mm. across, the petals oblong, $3 \mathrm{~mm}$. long, $2.5 \mathrm{~mm}$. wide, sparsely ciliate, one-fifth connate at the base; stamens 4 , equaling the petals in length, the anthers ovoid; rudimentary ovary conic, $1 \mathrm{~mm}$. long, the apex obtuse. Pistillate flowers not seen. Infructescences fasciculate, the pedi- 
cels 4-5 mm. long, puberulous, with 2 sub-basal ovate ciliate prophylla, the persistent calyx explanate, $2.5 \mathrm{~mm}$. in diameter. Fruit (immature) depressed-globose, longitudinally grooved, 5-6 mm. long, $8 \mathrm{~mm}$. in diameter, the stigma thin-discoid or navel-like. Pyrenes 4 , suborbicular in outline, $5 \mathrm{~mm}$. long, $4.5 \mathrm{~mm}$. wide, the dorsal surface palmately striate, esulcate and longitudinally depressed, the sides reticulately striate and sulcate, the endocarp woody.

CHINA: Chekiang: Wenchow, R. C. Ching 1819 (type, A; US), 1820 (fruit, A ; staminate flowers, US).

Ilex wenchowensis is localized in southeastern Chekiang, where it occurs on bushy slopes at an altitude of $600 \mathrm{~m}$. There it flowers in May. It is closely related to Ilex pernyi Franch. which differs in having .smaller leaves (1.3-2.5, rarely $3 \mathrm{~mm}$. long) with one or two spines on each side and oblong or obovate pyrenes, impressed only at the broader ends. From Ilex bioritsensis Hayata it differs in having 4 pyrenes. From Ilex centrochinensis S. Y. Hu it differs in its very short petioles and median longitudinally impressed pyrenes.

42. Ilex pernyi Franch. in Nouv. Arch. Mus. Hist. Nat. II, 5: 221. 1883, Pl. Dav. 1: 69. 1884; Oliv. in Hook. Ic. Pl. III, 6: pl. 1539. 1886; Forbes \& Hemsl. in Jour. Linn. Soc. Bot. 23: 117. 1886; Loes. ex Diels in Bot. Jahrb. 29: 436. 1900, in Nov. Act. Acad. Caes. Leop.Carol. Nat. Cur. 78: 278 (Monog. Aquif. 1: 278). 1901, et in Sarg. Pl. Wils. 1: 78. 1911; Farrer in Jour. Roy. Hort. Soc. 42: 77. 1916; Chun, Chin. Econ. Trees 223. 1921; Chung, Mem. Sci. Soc. China 1: 141. 1924; Rehd. in Jour. Arnold Arb. 7: 199. 1926, 8: 156. 1927; Comber in Notes Bot. Gard. Edinb. 18: 75. 1933; Chen, Ill. Man. Chin. Trees 658, fig. 550. 1937; S. Y. Hu in Ic. Pl. Omei. 2: pl. 162. 1946 .

An evergreen shrub or small tree up to $8 \mathrm{~m}$. high with pubescent branchlets, very short petioles, small coriaceous ovate-lanceolate spinose leaves, fasciculate inflorescences, rather large globose drupes up to $8 \mathrm{~mm}$. in diameter, and 4 palmately striate and sulcate pyrenes.

Branchlets straight, terete or subterete; third year's growth $4 \mathrm{~mm}$. in diameter, apricot-colored, covered with a dirty gray pubescence, minutely rimulose, the lenticels lacking; second year's growth $3 \mathrm{~mm}$. in diameter, dirty gray, densely pubescent; current year's growth $2 \mathrm{~mm}$. in diameter, angular, pubescent, fulvous, the terminal buds ovoid-conic, acute, pubescent. Leaves occurring even on the fifth year's growth, crowded together, appearing sessile; stipules callose, deltoid, acute, $0.75 \mathrm{~mm}$. long, $0.5 \mathrm{~mm}$. wide; petioles very short, $2 \mathrm{~mm}$. long, one-twelfth to one-eighth the length of the lamina, pubescent; lamina coriaceous, olivaceous, ovate or ovatelanceolate, $1.3-2.5 \mathrm{~cm}$., rarely $3 \mathrm{~cm}$. long, 5-14 mm. wide, broadest between the two anterior spines; base rounded or truncate; apex triangularly acuminate, the acumen $12-14 \mathrm{~mm}$. long, terminated by a strong spine $3 \mathrm{~mm}$. long; margin sinuate-dentate, 1-3 spines (usually 2) on each side, the two anterior ones strongest; midrib slightly impressed above, 
puberulent near the base, gradually becoming obscure toward the apex, elevated beneath, the lateral nerves 1-3 pairs, obscure beneath. Inflorescence fasciculate, axillary, on second year's growth; individual branches of the fascicles all uniflorous, the bracts lanceolate, membranous; pedicels sparsely puberulent, ciliate; flowers all 4-merous. Staminate inflorescence: pedicels $1 \mathrm{~mm}$. long, glabrous, with 2 suborbicular ciliate super-median prophylla; the calyx $2 \mathrm{~mm}$. across, deeply 4-lobed, the lobes broad-deltoid or semi-orbicular, ciliate; the corolla rotate, $7 \mathrm{~mm}$. across, the petals $3 \mathrm{~mm}$. long, broad-elliptic, the apical half ciliate; stamens slightly longer than the petals, the anthers $1 \mathrm{~mm}$. long; the rudimentary ovary conic-ovoid, $1.5 \mathrm{~mm}$. long, the apex obtuse. Pistillate inflorescence: pedicels $2 \mathrm{~mm}$. long; calyx as in the staminate flowers; corolla choripetalous, erect, the petals ovate, $2.5 \mathrm{~mm}$. long; the staminode two-thirds as long as the petals, the sterile anthers ovate; the ovary ovoid, the stigma discoid. Fruit globose or depressed-globose, 7-8 $\mathrm{mm}$. in diameter, the persistent calyx quadrangular in outline, $2.5 \mathrm{~mm}$. across, ciliate, the stigma thick-discoid, distinctly 4-lobed. Pyrenes 4, obovate or oblong in outline, $4.5-5.5 \mathrm{~mm}$. long, 3-3.5 mm. wide, impressed on the back at the wider end, palmately striate and sulcate on the back, reticularly striate and sulcate along the sides, the endocarp thick, woody.

CHINA: Anhwei: Wu-yuan, R. C. Ching 3245 (A). Kiangsi: Hwang-lung-shan, $Y$. K. Hsiung 5627 (A). Hupe i (Hupeh): Pa-tunghsien. H. C. Chow 337 (A, NY) ; W. Hupei, W. Y. Chun 3808 (A), 4172 (A), 4153 (US); A. Henry 5298 (US), 5298 A (A, NY); Ichang, E. $H$. Wilson 119 (staminate, A, US), 119 A (fruit, A, US), 271 (A, NY, US). Kweichow: Perny (ex Franchet). Kansu: Feng-s'an-ling, Farrer 16. Shensi: Tsing-ling, David. Szechuan: Mt. Uo-mi San [Mt. Omei], Fr. Hugh in 1899 (B); Kwang-yun-hsien, F. T. Wang 22595. Sikang: Pau-hsien-hsien (Mu-pin), K. L. Chu 2456 (SS), 3090 (SS); Tien-chuan, Y. S. Liu 1313 (A).

CULTIVATED: I have seen cultivated specimens from the Royal Botanic Gardens at Kew, England, from J. A. Havemeyer, and from the Arnold Arboretum.

Ilex pernyi is endemic to the Tsing-ling Range, the climatic barrier in central China responsible for the very different aspects of the floras of North and South China. Ilex pernyi is found on both sides of this range, from Kansu down to the foothills of Hwang-shan in Anhwei. On the western limit of its area of distribution, the plant, as Farrer reported, grows as an "ugly and graceless little dumpy shrub... woodland of the drier ranges." On the eastern and southern sections of its area of distribution it is a shrub or small tree in forests growing at an altitude of $1800 \mathrm{~m}$. (ex Chun). It flowers in April and May, and the fruit becomes red in October.

On the field notes attached to the specimen labeled W. Y. Chun 4172, the collector is erroneously recorded as " $R$. C. Ching."

The fruits of Y.S. Liu 1313 contain either two or three pyrenes. This may indicate that the two-pyrened Ilex bioritsensis Hayata is nothing 
but a variety of Ilex pernyi. The small ovate-lanceolate shiny leaves and the palmately striate-sulcate, thickly woody endocarp of Ilex pernyi closely relate it to Ilex georgei Comber, which differs in having only two pyrenes.

43. Ilex georgei Comber in Notes Bot. Gard. Edinb. 18: 50. 1933; Hand.-Mzt. Symb. Sin. 7: 656. 1933; Merr. in Brittonia 4: 100. 1941.

Ilex pernyi Franch. var. manipurensis Loes. in Nov. Act. Acad. Caes. Leop.-Carol. Nat. Cur. 78: 279 (Monog. Aquif. 1: 279). 1901.

Ilex pernyi sensu Loes. in Sarg. P1. Wils. 1: 78. 1911, in part.

A spinose-leaved evergreen shrub up to $6 \mathrm{~m}$. high with pubescent branchlets, lanceolate (rarely ovate) leaves, fasciculate inflorescences, obovoid-ellipsoid red fruits each with 1 or 2 pyrenes.

Branchlets rather stout, pubescent, cinereous or light brown; third year's growth $4 \mathrm{~mm}$. in diameter, hirsute, the lenticels lacking; second year's growth $3.5 \mathrm{~mm}$. in diameter; current year's growth subterete, 2-2.5 $\mathrm{mm}$. in diameter, longitudinally shallowly striate-sulcate, densely pubescent, the terminal bud conic, pubescent. Leaves occurring even on the fourth year's growth, 2-5 mm. apart; stipules broadly ovate, acute; petioles 1-2 $\mathrm{mm}$. long, one-twentieth to one-fifteenth the length of the lamina, pubescent, often covered by the decurrent base of the leaf; lamina thickly coriaceous, olivaceous, shiny above, opaque beneath, lanceolate, ovatelanceolate or rarely ovate, $2-4.5 \mathrm{~mm}$. long, 7-15 mm. wide; rounded or cordate at the base; acuminate at the apex, the acumen $10 \mathrm{~mm}$. long, terminating in a spine $3 \mathrm{~mm}$. long; margin thickened, recurved, subentire, with 4-7 spines on each side; midrib pubescent, shallowly impressed above, elevated beneath, the lateral nerves 5-7 on each side, indistinct above, evident beneath, the reticulation of the veinlets obscure on both surfaces. Inflorescences fasciculate, axillary on second year's growth. Staminate inflorescences: individual branches of the fascicles 1-3-flowered, the uniflorous pedicels 2-4 mm. long, when 3-flowered the peduncles $1 \mathrm{~mm}$. long, both sparsely and minutely pubescent, the bracts membranous, ovate, obtuse, ciliate, the prophylla 2, membranous, submedian, pubescent; flowers 4-merous, calyx 1.5-2 mm. across, 4-lobed, lobes ovate, obtuse or rounded, ciliate; corolla rotate, 4-5 $\mathrm{mm}$. across, the petals $2 \mathrm{~mm}$. long, minutely and sparsely ciliate, one-tenth connate at the base; stamens longer than the petals, the anthers oblong; rudimentary ovary subglobose or ovoid, obtuse at the apex, sometimes obscurely 2-lobed. Pistillate flowers not seen. Fruit usually paired, obovoid-ellipsoid, 4-6 $\mathrm{mm}$. long, 3-4 mm. thick, the pedicels $2 \mathrm{~mm}$. long, pubescent, the persistent calyx ciliate, the stigma discoid. Pyrenes 1 or 2, obovoid-oblong, rarely suborbicular in outline, slightly dorso-ventrally compressed, flattened on one side, $4.5 \mathrm{~mm}$. long, $2.5-3 \mathrm{~mm}$. wide, longitudinally (almost palmately) 7-9-striate and shallowly sulcate on the back, the ends obtuse, the endocarp thickly woody.

CHINA: Yunnan: Tengyueh, G. Forrest 7577 (A), 9608 (A), 9712 (A), 16061 (fruit, isotype, A), 26251 (staminate flowers, isotype, A), 26254 
(US) ; J.F. Rock 7677 (A, NY, US) ; San-ying-pa, C. Schneider 394 (A); without precise locality, H. T. Tsai 57247 (A); Mien-ning, T. T. Yu 17967 (A). Sikang: Ta-chien-lu, E. H. Wilson $119 B$ (A).

NORTH BURMA: F. K. Ward 463 (A, NY).

Ilex georgei is confined to western and southwestern Yunnan and adjacent Burma, where it grows as a shrub in dense thickets, on dry slopes, or in side valleys at altitudes of 1800-2700 m. Its greenish staminate flowers appear in late March and on into May, and the fruit becomes red in October.

E. H. Wilson 119 is a mixture of material collected in Hupei and Sikang. The Hupei material has 4 pyrenes, while the Sikang (Ta-chienlu) material has a much prolonged leaf-apex, as well as smaller fruits maturing only 2 pyrenes each. I have distinguished this latter material in the Arnold Arboretum herbarium as 119B.

The indumentum and the lack of uniformity in the number of pyrenes of Ilex georgei closely relates it to Ilex ciliospinosa Loes., but in the latter the leaves are less coriaceous and ovate or ovate-elliptic in shape, with a less prominent apex. The fruit is larger $(8-10 \mathrm{~mm}$. long), as are the pyrenes.

44. Ilex ciliospinosa Loes. in Sarg. Pl. Wils. 1: 78. 1911; S. Y. Hu in Ic. Pl. Omei. 2: pl. 161. 1946.

Ilex bioritsensis Hayata var. ciliospinosa (Loes.) Comber in Notes Bot. Gard. Edinb. 18: 43. 1933.

An evergreen shrub or small tree up to $7 \mathrm{~m}$. high, with densely pubescent branchlets, elliptic or ovate-elliptic weakly spinose leaves, fasciculate inflorescences, ellipsoid drupes $8 \mathrm{~mm}$. long, and 1-3 palmately striate and sulcate pyrenes.

Branchlets terete, dirty-gray, pubescent; fourth year's growth $4 \mathrm{~mm}$. in diameter, reticulately rimulose, pubescent, the lenticels lacking, the leaf-scars broadly deltoid; second year's growth $3 \mathrm{~mm}$. in diameter, densely pubescent, rugose; current year's growth subterete, longitudinally striate, light brown, densely pubescent, the terminal buds ovoid, pubescent, the apex cuspidate. Leaves occurring even on the fourth year's growth, 2-8 $\mathrm{mm}$. apart; stipules callose, often tricuspidate; petioles $2-3 \mathrm{~mm}$. long, one-fifteenth to one-tenth the length of the lamina, pubescent and rugose; lamina coriaceous, olivaceous, elliptic or ovate-elliptic, $2.5-4.5 \mathrm{~cm}$. long, $1-2.5 \mathrm{~cm}$. wide; round or rarely obtuse at the base; shortly acuminate or acute at the apex, the acumen $3-5 \mathrm{~mm}$. long, terminating in a weak spine; margin serrate, with 4-6 spines on each side; midrib impressed and pubescent above, elevated and glabrous beneath, the lateral nerves 4-6 on each side, indistinct above, evident beneath, arching upward, near the margin reticulate. Inflorescences paucifasciculate, fascicles 2-5-flowered, axillary on last year's growth, the bud-scales persistent, ovate, acute, sparsely pubescent, ciliate, the bracts lanceolate, ciliate; the prophylla 2, median or submedian, not reaching the calyx, individual branches of the fascicles all uniflorous, the pedicels $2-3.5 \mathrm{~mm}$. long, pubescent or glabres- 
cant; flowers 4-merous. Staminate flowers: calyx $3 \mathrm{~mm}$. broad, deeply lobed, the lobes ovate, deltoid, ciliate, obtuse or rounded at the apex; corolla rotate, $6 \mathrm{~mm}$. broad, the petals ovate, $3 \mathrm{~mm}$. long, $2 \mathrm{~mm}$. wide, minutely ciliate at the apex, one-eighth connate at the base; stamens longer than the petals, the anthers oblong; rudimentary ovary ovoid, 1 $\mathrm{mm}$. in diameter, the apical end indistinctly sulcate. Pistillate flowers: calyx as in the staminate flowers; corolla erect, choripetalous, $2.5 \mathrm{~mm}$. long; staminodes about equaling the petals in length, the sterile anthers sagittate; ovary oblong, $2 \mathrm{~mm}$. in diameter, truncate at the apex, the stigma discoid. Fruit solitary or paired, seldom 3 in a fascicle, ellipsoid, $8 \mathrm{~mm}$. long, the pedicels $2-4 \mathrm{~mm}$. long, pubescent or glabrescent, the persistent calyx 2-3 mm. across, quadrangular in outline, ciliate; the stigma thinly discoid. Pyrenes 1-3; obovoid in outline, palmately striate and sulcate, when 1, suggestive of a wheat-grain with a narrow shallow groove on the ventral side, when 2, (developing) dorso-ventrally compressed, slightly convex on the back, flat on the ventral side, when 3, obovoid, $6 \mathrm{~mm}$. long, $4 \mathrm{~mm}$. wide, the endocarp thick-woody.

CHINA: Szechuan: Mt. Omei, W. C. Chong $6591(\mathrm{Sz}) ; C . Y$. Chiao \& C. S. Fan 871 (A); W. P. Fang 14800 (Sz); Y. S. Liu 1447 (A); T. H. Tu 720 (SS); E. H. Wilson 3316 (A); Opien-hsien, W. C. Cheng $6216(\mathrm{Sz}), 6456(\mathrm{Sz})$; S. N. Hsu $69(\mathrm{Sz})$; C. Y. Y ao 2808 (SS), 4279 (SS), Y.S. Liu 2058 (A) ; T. T. Yu 639 (A), 663 (A), 835 (A) ; Chienshi-hsien, E. H. Wilson 996 (Isotype, A), Wa-shan, E. H. Wilson $996 \mathrm{~A}$ (A); locality not clear, E. H. Wilson 3319 (A). Yunnan: Mengtze, A. Henry 11169 (A).

CULTIVATED: I have seen a specimen from Upper Bank Nurseries, located at Media, Pennsylvania.

Ilex ciliospinosa is endemic to western Szechuan, where it grows as a shrub or small tree in bamboo forests or in thickets at an altitude of 1700-2300 m. The greenish flowers appear in early May, and the fruit becomes red in September.

Comber, presuming that Wilson's specimens were juvenile forms, reduced Ilex ciliospinosa to a variety of Ilex bioritsensis Hayata. But Wilson's specimens were not juvenile forms, since most of the branchlets show plainly five years of growth. The leaves on the four-years' growth are the same in shape, texture, and margin as those on the current year's twigs. Furthermore, the specimen T.T. Yu 663 was collected from a tree 20 feet high. The spines of the leaves of this specimen are as weak as those on a 5-foot shrub. In this spinose group of Ilex, the "species" show much intergradation in the size and dentation of the leaves, in the indumentum, and in the number of pyrenes. Hence the reduction of any of them to varieties would result, consistently, in further reductions. Probably all would end up as varieties of Ilex dipyrena Wall., the oldest binomial of the group. Morphologically there is just as much resemblance and just as much difference between Ilex ciliospinosa Loes. and Ilex bioritsensis Hayata as between Ilex bioritsensis and Ilex dipyrena. Until cytological and genetic techniques can be applied to this group, it is better to keep all the members in specific rank. 
In its weak and more numerous spines and in the inconsistent number of its pyrenes (1-3), Ilex ciliospinosa is very closely related to Ilex dipyrena, which differs in having large $(6-10 \mathrm{~cm}$. long) leaves and glabrescent branchlets.

45. Ilex bioritsensis Hayata in Jour. Coll. Sci. Tokyo 30: 53. 1911; Comber in Notes Bot. Gard. Edinb. 18: 42. 1933; Kanehira, Formosan Trees 371, fig. 325. 1936.

Ilex reitchii Veitch, New Hard. P1. W. China 4, 1912, nomen subnudum; Anon. in Gard. Chron. III. 52: 289. 1912.

Ilex pernyi Franch. var. veitchii Bean, Trees Shrubs Hardy Brit. Isles 1:

650. 1914, nomen nudum; Rehd. in Mitteil. Deutsch. Dendr. Ges. 23: 263. 1914, descr.

Ilex diplosperma S. Y. Hu in Ic. Pl. Omei. 2: pl. 163. 1946.

An evergreen shrub or small tree up to $10 \mathrm{~m}$. high, with glabrescent or sparsely puberulent branchlets, ovate or quadrangular strongly spinose leaves, fasciculate inflorescences, large fruits $(8-10 \mathrm{~mm}$. in diameter) and two dorso-ventrally compressed, palmately striate and sulcate, thick-woody pyrenes.

Branchlets glabrescent or sparsely puberulent; third year's growth subterete, cinereous, 3-4 mm. in diameter, smooth, the lenticels lacking; second year's growth $2.5 \mathrm{~mm}$. in diameter, longitudinally striate rugose; current year's growth $2 \mathrm{~mm}$. in diameter, striate and ridged, the terminal buds puberulent, conic, acute at the apex, the scales ciliate. Leaves occurring even on the fourth year's growth, 5-15 mm. apart; stipules callose, ovate, $0.8 \mathrm{~mm}$. long, acute, constricted near the base; petioles $3 \mathrm{~mm}$. long, onefifteenth to one-twelfth the length of the lamina, pubescent; lamina thickcoriaceous, olivaceous or ochraceous, shiny above, opaque beneath, ovate-quadrangular, $2.5-6 \mathrm{~cm}$. long (usually $3 \mathrm{~cm}$. long), $1.5-3.5 \mathrm{~cm}$. (usually $2 \mathrm{~cm}$.) wide; base rounded or truncate; apex acuminate, the acumen $5-15 \mathrm{~mm}$. long, terminated by a spine $3 \mathrm{~mm}$. long; margin sinuate, with 3 or 4 strong spines on each side; midrib sulcate above, puberulent, elevated beneath, the lateral nerves 4-6 pairs, evidently impressed above, obscure or slightly elevated beneath; reticulation of the veinlets obscure on both surfaces. Inflorescences fasciculate, axillary on the second year's growth, the individual branches of the fascicles all uniflorous, the bracts ovate, ciliate, $1.75 \mathrm{~mm}$. long; flowers 2-4-merous. Staminate flowers: pedicels $2 \mathrm{~mm}$. long, glabrous, with 2 large ovate ciliate prophylla extending to the calyx; the calyx patelliform, $3 \mathrm{~mm}$. across, the lobes broadly deltoid, obtuse, sparsely ciliate; corolla rotate, the petals broad-elliptic, $3 \mathrm{~mm}$. long, one-eighth connate at the base; stamens longer than the petals, the anthers oblong; rudimentary ovary ovoid, $1 \mathrm{~mm}$. in diameter. Pistillate flowers: pedicels $2 \mathrm{~mm}$. long, glabrous, with 2 basal prophylla; calyx as in the staminate flowers; corolla choripetalous; staminodes half the length of the petals, the sterile anthers cordate; ovary oblong-ovoid, 2-3 $\mathrm{mm}$. long, the stigma thin-discoid. Fruit ellipsoid, 8-10 $\mathrm{mm}$. long; the stigma discoid. Pyrenes 2, dorso-ventrally compressed, ovate or sub- 
orbicular in outline, 5-6 mm. long, 4-5 mm. wide, palmately $8-10$-striate and sulcate on the dorsal surface, 5-striate on the ventral surface, the endocarp woody.

CHINA: Kweichow: Fan-ching-san, Steward, Chiao \& Cheo 390 (A, US), 774 (A, NY, US) ; P. C. Tsoong 1041 (SS) ; Yin-kiang, Y. Tsiang 7736 (NY), 7965 (NY). Szechuan: Nan-chuan-hsien, W. T. Fang 640 (SS), 976 (A, SS) ; Mt. Omei, W. P. Fang 3097 (A, NY), 12879 (A, Sz, US), 16431 (Sz) ; O-pien-hsien, T. S. Chao 604 (SS); Muli, J. F. Rock 5211 (A, US), 17368 (A, US) ; Ning-yuan-fu, C. Schneider 942 (A); Lang-pa (Lolo-lang), C. Schneider 1070 (A), 1523 (A); Wu-shan, E. H. Wilson 1028 (A, NY, US); Yung-ching-hsien, Wa-wu-shan, C. W. Yao 2224 (SS); without precise locality, H.C. Chow $10005(\mathrm{Sz})$. Y un nan : Li-kiang, K. M. Feng 622 (A) ; Chung-tien, K. M. Feng 966 (A); Yungning, G. Forrest 20644 (US) ; Che-kia, E. E. Maire 525 (A); Ho-kia-keou, E. Maire 3330 (NY, US) ; Yi-liang-hsien, H. T. Tsai 52130 (A) ; without precise locality, T. T. Yu 5446 (A). T a iw an: N. Fukuyama \& $T$. Suzuki 15207 (TU); E. Matuda 1208 (TU); R. Kanehira \& S. Sasaki 21807 (US); E. H. Wilson 10058 (A, US).

CULTIVATED: I have seen sterile specimens of juvenile plants from Kew and the Arnold Arboretum under the name Ilex pernyi var. veitchii Rehd.

This plant was first recorded from Bioritsu, Taiwan. Additional material has been collected from Kweichow, Szechuan, and Yunnan. Both on the Island and on the mainland it grows in forests as a small tree up to $10 \mathrm{~m}$. high. It flowers in late April.

All the spinose-leaved Ilex characterized by medium-sized leaves with rather strong spines and two-pyrened fruits have been placed under this species. There is great variation in its leaf-form and indumentum. The stems of some specimens are almost glabrous, but others are as pubescent as those of Ilex pernyi Franch.

46. Ilex perryana, sp. nov.

Ilex pernyi sensu Marquand in Jour. Linn. Soc. Bot. 48: 168. 1929; sensu F. K. Ward in Gard. Chron. III, 92: 232. 1932, non Franch.

Ilex pernyi Franch. forma, Anon. in Notes Bot. Gard. Edinb. 17: 270. 1930.

Ilex pernyi Franch. var., Anon. in Notes Bot. Gard. Edinb. 17: 304.1930.

Ilex georgei Comber var. rugosa Comber in Notes Bot. Gard. Edinb. 18: 51. 1933; Merrill in Brittonia 4: 100. 1941.

Frutex prostratus; ramulis brevissime pubescentibus; foliis spinosis, crasse coriaceis, supra nitidis et rugosis, subrhomboideis, raro ellipticis, $1-3 \mathrm{~cm}$. longis, 7-15 mm. latis, basi obtusis, raro rotundatis, costa supra impressa, subtus obscura; inflorescentiis paucifasciculatis, axillaribus; of unifloribus, pedicellis $2-3.5 \mathrm{~mm}$. longis, calycibus ciliatis, corolla rotata, petalis $1.5 \mathrm{~mm}$. longis, eciliatis, staminibus quam petalis aequilongis vel longioribus; \& unifloribus, pedicellis $3-4 \mathrm{~mm}$. longis, ovario ovoideo, $1.5 \mathrm{~mm}$. longo; fructibus subgloboso-ellipsoideis, 6-7 mm. diametro; pyrena 1 , subglobosa, dorso-ventraliter compressa, $5 \mathrm{~mm}$. diametro, dorso 
palmatim striata et esulcata, ventro canaliculato, endocarpio lignescente.

A prostrate evergreen spinose shrub $20-30 \mathrm{~cm}$. high with stout puberulent branchlets, small hexangularly subrhomboid rugose leaves, paucifasciculate inflorescences, small subglobose fruits, and a single palmately striate esulcate subglobose pyrene in each fruit.

Branchlets stout, straight, tuberculate with elevated leaf-scars, normal annual growth 2-3 mm. long, the third year's growth and the current year's growth almost alike in thickness and texture, 3-4 mm. in diameter, minutely puberulent, the lenticels lacking, the terminal buds ovoid, puberulent, well protected by crowded leaves or petioles. Leaves occurring even on sixth year's growth, 2-3 mm. apart; stipules callose, ovate, ca. $0.6 \mathrm{~mm}$. long, acute, slightly constricted at the base; petioles $1-2 \mathrm{~mm}$. long, onefifteenth to one-tenth as long as the lamina, glabrous or minutely puberulent, dorso-ventrally flattened; lamina thick-coriaceous, olivaceous or brunneous-olivaceous, very shiny and rugose above, opaque and smooth beneath, hexangular-subrhomboid, rarely elliptic, 1-3 cm. long, 7-15 mm. wide; obtuse, rarely rounded at the base; broadly deltoid at the apex, the tip acute, terminated by a spine $2 \mathrm{~mm}$. long; margin subentire-sinuate, with 2 or 3 spines on each side; midrib deeply impressed above, glabrous, slightly elevated beneath, the lateral nerves 3 or 4 pairs, deeply impressed above, obscure beneath, the reticulation of the veinlets impressed above, inconspicuous beneath. Inflorescence paucifasciculate, axillary on second year's growth; fascicles with 2-4 flowers, the bud-scales persistent, cartilaginous, suborbicular, glabrescent; flowers all 4-merous. Staminate inflorescences: individual branches of the fascicles uniflorous, the bracts ovate, obtuse, sparsely puberulent, ciliate; pedicels $2-3.5 \mathrm{~mm}$. long, glabrous, with 2 submedian or basal glabrous ciliate prophylla; calyx patelliform, $3 \mathrm{~mm}$. across, deeply 4-lobed, lobes ovate, $0.9 \mathrm{~mm}$. long, $0.75 \mathrm{~mm}$. wide at the base, glabrous, minutely ciliate; corolla rotate, 4-5 mm. across, the petals ovate, $1.5 \mathrm{~mm}$. long, eciliate, one-sixth connate at the base; stamens equaling or slightly longer than the petals, the anthers ovoid-oblong, $0.75 \mathrm{~mm}$. long; rudimentary ovary pulvinate, obscurely lobed. Pistillate inflorescences: individual branches of the fascicles uniflorous, the calyx and corolla as in the staminate; ovary ovoid, $1.5 \mathrm{~mm}$. long, constricted below the discoid stigma. Fruit subglobose-ellipsoid, 6-7 $\mathrm{mm}$. in diameter, the fruiting pedicels $3-4 \mathrm{~mm}$. long, the stigma discoid, orbicular. Pyrene 1, subglobose, slightly dorso-ventrally compressed, $5 \mathrm{~mm}$. in diameter, palmately striate and esulcate on the back, canaliculate on the ventral side, the endocarp thickly woody.

CHINA: Yunnan: G. Forrest 17538 (A), 18006 (A); Newahlung, T. T. Yu 19330 (A); Barcuhwang, T. T. Y 20942 (TyPE, A).

NORTH BURMA: F. K. Ward 224 (A), 9873 (A).

Ilex perryana is a prostrate dwarf shrub confined to the alpine flora of eastern Himalaya, where it grows on open rocky slopes at altitudes of 3000-3650 m. The flowers appear in June and the fruit turns red in November. 
In its small leaves, few spines, and subglobose pyrenes this alpine Ilex is closely related to Ilex pernyi Franch., which differs in having leaves with a smooth surface, prolonged apex, and truncate base, and fruits which are consistently 4-pyrened. It can easily be distinguished from all the other spinose species of Ilex by its prostrate habit, and its striate esulcate pyrenes.

The descriptions of the staminate and pistillate flowers were drawn respectively from Ward 9873 and $Y u 19330$.

This species is named in honor of Dr. Lily M. Perry of the Arnold Arboretum, whose assistance and advice has been of great value.

\section{Series 3. DEnticUlataE, ser. nov.}

Arbor vel frutex; foliis crasse coriaceis, raro subcoriaceis, crenulatoserratis, serratis vel raro integris; inflorescentiis fasciculatis, pseudopaniculatis vel pseudoracemosis; floribus 4-meris; corolla $\hat{o}$ basi connata, $q$ choripetala; fructibus globosis, stigmate umbilicato; pyrenis rugosis et caveatibus, raro palmatim striatis; endocarpio lapidoso.

\section{Key to THE Species}

A. Ovary and fruit pubescent.

B. Fruiting pedicels ca. $4 \mathrm{~mm}$. long; leaves elliptic or ovate-elliptic, $3-7 \mathrm{~cm}$. long, 1.3-2.5 cm. wide, the lower surface pubescent; petioles 3-6 mm. long. (Hainan and Indo-China)..47. I. pubilimba.

BB. Fruiting pedicels ca. $8 \mathrm{~mm}$. long; leaves oblong or oblong-elliptic, 10-15 cm. long, $4.5-7.5 \mathrm{~cm}$. wide, the lower surface glabrous; petioles 20-22 mm. long. (Hainan).........48. I. kaushue.

AA. Ovary and fruit glabrous.

B. Branchlets, leaves and inflorescences densely hirsute. (Kwangsi).. ............................49. I. nanningensis.

BB. Branchlets and inflorescences glabrous, glabrescent or puberulous, the leaves always glabrous.

C. Leaves thick-coriaceous, $10-17 \mathrm{~cm}$. long, 4.5-7.5 cm. wide; individual branchlets of the staminate inflorescences 3-9flowered. (East China and Japan)........50. I. latifolia.

CC. Leaves coriaceous or subcoriaceous, rarely up to $10 \mathrm{~cm}$. long; individual branchlets of the staminate inflorescence 1-3flowered.

D. Leaves entire; fruits $5 \mathrm{~mm}$. in diameter, smooth when dry. (Taiwan) .................. I. suzukii.

DD. Leaves crenulate-serrulate, serrate or rarely subentire; fruits 6-15 mm. in diameter, when dry usually wrinkled. E. Fruits 5-7 mm. in diameter; pyrenes $4-5 \mathrm{~mm}$. long. F. Leaves coriaceous, the apex obtuse or rarely abruptly and shortly acuminate; fruiting pedicels 4-8 $\mathrm{mm}$. long.

G. Branchlets glabrous; margin of leaves dense$1 y$ and often irregularly serrate; infructescences pseudoracemose or fasciculate; fruiting pedicels 6-8 mm. long. (India and Southwest China)....52. I. denticulata. 
GG. Branchlets puberulous; margin of leaves remotely serrate; infructescences fasciculate, the fruiting pedicels ca. $4 \mathrm{~mm}$. long. (Hongkong and vicinity).....53. I. graciliflora.

FF. Leaves subcoriaceous, the apex long-acuminate, the acumen $10-16 \mathrm{~mm}$. long; fruiting pedicels 10-12 mm. long. (Kwangtung)..54. I. tsangii. EE. Fruit 10-15 mm. in diameter; pyrenes $7-12 \mathrm{~mm}$. long. F. Mature fruit solitary; fruiting pedicels $2-4 \mathrm{~mm}$. long; pyrenes obovate in outline, $10-12 \mathrm{~mm}$. long. (Kwangsi) .............55. I. chingiana.

FF. Mature fruits fasciculate; fruiting pedicels $6-10$ $\mathrm{mm}$. long; pyrenes $7-9 \mathrm{~mm}$. long.

G. Leaves elliptic or obovate; reticulation of the veinlets prominent on both surfaces; pyrenes oblong in outline, both ends obtuse or one end emarginate. (Taiwan)............ ................... It uraiensis.

GG. Leaves oblong, ovate-elliptic or oblanceolate; reticulation of the veinlets obscure above; pyrenes broad-elliptic in outline, the ends pointed.

H. Branchlets castaneous or nigrescent; leaves shiny above with caudate apex, the acumen $7-16 \mathrm{~mm}$. long; the base obtuse or rounded. (South China)...... ................57. I. subficoidea.

HH. Branchlets cinereous; leaves opaque on both surfaces, with acuminate apex, the acumen 5-10 mm. long; base cuneate. (Hainan)........58. I. nuculicava.

47. Ilex pubilimba Merr. \& Chun in Sunyat. 5: 109. 1940.

Ilex hirsuticarpa Tardieu-Blot in Not. Syst. XII. 15: 120. 1945, et in Fl. Gén. Indo-Chine Suppl. 1: 776. 1948. Syn. nov.

A densely pubescent evergreen tree up to $15 \mathrm{~m}$. high with coriaceous, elliptic, shortly acuminate, crenate-serrate leaves, fasciculate inflorescences, pubescent ovary, short fruiting pedicels $(2-4 \mathrm{~mm}$.), and depressed globose fruits $7 \mathrm{~mm}$. in diameter.

Branchlets straight, subterete, fuscous when dry; third year's growth $4 \mathrm{~mm}$. in diameter, pubescent, longitudinally rimulose, the lenticels obscure, the leaf-scars semi-orbicular; second year's growth pubescent; current year's growth $2-2.5 \mathrm{~mm}$. in diameter, subterete, very densely pubescent, the indumentum fuscous; terminal buds small, naked, pubescent. Leaves occurring also on the second year's growth, 2-12 mm. apart; stipules callose, deltoid, pubescent at the base; petioles $3-6 \mathrm{~mm}$. long, one-twentieth to one-twelfth the length of the lamina, densely pubescent, canaliculate above; lamina thick-coriaceous, when dry cinereous-olivaceous and shiny above, paler with over-all pubescence beneath, elliptic, rarely 
ovate-elliptic or lanceolate, $3-7 \mathrm{~cm}$. long, $1.3-2.5 \mathrm{~cm}$. wide; base rounded, obtuse or cuneate; apex shortly acuminate, the acumen 3-10 $\mathrm{mm}$. long, the tip obtuse; margin crenate-serrate, slightly recurved when dry; midrib impressed and pubescent above, elevated beneath, lateral nerves obscure. Inflorescence fasciculate, axillary, on last year's growth, short-pedicellate; bracts ovate to semi-orbicular, densely pubescent; flowers 4-merous. Staminate flowers: individual branches of the fascicles 1-3-flowered, 3 -flowered branches cymose, the peduncle $0.5-1 \mathrm{~mm}$. long, the pedicels 2-3 mm. long, with 2 basal prophylla; calyx patelliform, $1.5-2 \mathrm{~mm}$. in diameter, rugose, 4-lobed, the lobes rounded, ciliate; corolla rotate, $6 \mathrm{~mm}$. in diameter, the petals oblong, $2.5 \mathrm{~mm}$. long, ciliate, one-ninth connate at the base; stamens slightly shorter than the petals, the anthers ovoid, 0.75 $\mathrm{mm}$. long; rudimentary ovary conical, $1 \mathrm{~mm}$. in diameter, the apex obtuse. Pistillate flowers: individual branches of the fascicles uniflorous, the calyx and corolla as in the staminate flowers; staminodes one-third the length of the petals, the sterile anthers ovate; ovary subglobose, $1.75 \mathrm{~mm}$. in diameter, sparsely but distinctly pubescent, the stigma discoid, convex. Fruit depressed globose, $7 \mathrm{~mm}$. in diameter, the fruiting pedicel $3-4 \mathrm{~mm}$. long, pubescent, the persistent calyx explanate, orbicular in outline, $2 \mathrm{~mm}$. across, shallowly 4-lobed, the lobes ciliate, the stigma thinly discoid, orbicular. Pyrenes 4, suborbicular or oblong in outline, 4-5 mm. long, 3.5-4 mm. wide, rugose, flattened or slightly impressed on the back, the endocarp woody.

CHINA: Ha in an: Kan-en, S. K. Lau 5974 (A); Bak-sa, S. K. Lan 25742 (material for the description of the staminate flower) (A); S. K. Lau 26069 (material upon which-description of the pistillate flower is drawn) (A); Yai-chow, H. Y. Liang 62579 (A, K, NY, US), 62624 (TYpe, A; K, NY, US) ; without precise locality, H. Y. Liang 63624 (A, NY) ; C. Wang 35188 (A, NY).

INDO-CHINA: Tonkin: W.T.Tsang 30339 (A); Annam: Poilane 8235 (A, ISOTYPE of $I$. hirsuticarpa).

Ilex pubilimba Merr. \& Chun has been recorded from Hainan Island and Indo-China, where it grows as a big tree in mixed forests. The whitish yellow flowers appear in March.

The vegetative characters, especially the indumentum, and the leaf form of Ilex pubilimba are very similar to those of the very closely allied species Ilex nanningensis Hand.-Mzt. Professor Merrill has written on the type specimen and on other Hainan material "= Ilex nanningensis Hand.Mzt." On closer examination, however, these two species can easily be distinguished from each other by the size of their fruits, the length of the petioles and fruiting pedicels, and the indumentum of the ovary. In Ilex nanningensis the fruits are $10 \mathrm{~mm}$. in diameter, the petioles one-tenth to one-sixth as long as the lamina, the fruiting pedicels $6-8 \mathrm{~mm}$. long, and the ovary glabrous. In Ilex pubilimba the fruits are $7 \mathrm{~mm}$. in diameter, the petioles one-twentieth to one-twelfth as long as the lamina, the fruiting pedicels $3-4 \mathrm{~mm}$. long, and the ovary pubescent. 
48. Ilex kaushue, sp. nov.

Arbor; ramulis pubescentibus; foliis oblongis vel oblongo-ellipticis, $10-15 \mathrm{~cm}$. longis, $4.5-7.5 \mathrm{~cm}$. latis, basi obtusis vel cuneatis, apice acutis vel breviter acuminatis, margine serratis vel biserratis; costa supra impressa pubescente, subtus elevata, nervis lateralibus 14 vel 15 paribus; inflorescentiis fasciculatis vel pseudoracemosis, pedicellis $8 \mathrm{~mm}$. longis, pubescentibus; fructibus subglobosis, $11 \mathrm{~mm}$. longis, 9-10 mm. diametro; pubescentibus; calycibus persistentibus ciliatis, stigmate umbilicato; pyrenis 4, ca. $7.5 \mathrm{~mm}$. longis, 4.5-5 mm. latis, endocarpio lapidoso.

An evergreen tree with densely puberulent branchlets, large oblong thincoriaceous serrate or double-serrate leaves, fasciculate infructescence, large subglobose puberulent fruits, and 4 reticulately striate sulcate wrinkled and pitted pyrenes.

Branchlets straight, subterete, brown, longitudinally ridged and canaliculate; second year's growth $4 \mathrm{~mm}$. in diameter, the lenticels lacking, the leaf-scars deltoid-semi-orbicular; current year's growth angular, longitudinally plicate, $3.5 \mathrm{~mm}$. in diameter; densely puberulent especially in the grooves; terminal buds acute-conic, pubescent. Leaves occurring also on second year's growth, 10-18 mm. apart; stipules callose, often hidden; petioles pubescent, slender, 20-22 mm. long, one-sixth to one-fifth the length of the lamina, subterete and angular, very narrowly canaliculate above; lamina thin-coriaceous, brunneous-olivaceous, shiny above, paler and opaque beneath; oblong or oblong-elliptic, 10-18 cm. long, 4.5-7.5 $\mathrm{cm}$. wide; base obtuse or cuneate; apex acute or very shortly acuminate, the acumen 3-6 $\mathrm{mm}$. long; margin serrate or double-serrate; midrib impressed, sparsely and minutely puberulent above, prominent, elevated and keeled beneath, the lateral nerves in 14 or 15 pairs, prominent on both surfaces; the reticulation of the veinlets dense and evident on both surfaces. Infructescences fasciculate or pseudoracemose, the rachis up to $9 \mathrm{~mm}$. long, densely puberulent; bracts caducous, the lower persistent ones cartilaginous, broad-deltoid, obtuse, coarsely ciliate, the basal appendages acute, pubescent; pedicels $8 \mathrm{~mm}$. long, pubescent; persistent calyx explanate, ca. $5 \mathrm{~mm}$. across, puberulent, 4-lobed, the lobes broad-deltoid, very acute or cuspidate, sparsely ciliate. Fruit subglobose or ellipsoid, ca. $11 \mathrm{~mm}$. long, $9-10 \mathrm{~mm}$. in diameter, the exocarp densely puberulent, the stigma navel-like. Pyrenes 4, oblong in outline, ca. $7.5 \mathrm{~mm}$. long, 4.5-5 $\mathrm{mm}$. wide, reticulately striate and sulcate, wrinkled and pitted, the endocarp stony.

CHINA: Hainan: Taam-chau, W. T. Tsang. 864 (LU 16363) (TYPE, A; LU, US).

This species is endemic to Hainan Island. The local name is "kaushue." In September the fruits become yellow.

The large leaves, the pseudoracemose infructescences, and the wrinkled and pitted pyrenes of Ilex kaushue suggest a relationship with Ilex latifolia Thunb., but the latter has smaller glabrous fruits, glabrous branchlets, and thick-coriaceous leaves with no evident reticulations of the veinlets. 
On the labels distributed by the Herbarium of Lingnan University, the notation "flowers yellow" is given. Since the specimens at hand show no evidence of the flowering stage, I assume that there may have been a mechanical error in the preparation of the labels. The color yellow as given undoubtedly refers to the fruit, since the specimen was collected in September.

49. Ilex nanningensis Hand.-Mzt. in Sinensia 5: 2. 1934; Chun in Sunyat. 4: 225. 1940.

A densely pubescent evergreen tree up to $20 \mathrm{~m}$. high with coriaceous elliptic or lanceolate, shortly acuminate crenate-serrate leaves, fasciculate inflorescences, large subglobose fruits, $10 \mathrm{~mm}$. in diameter, and long fruiting pedicels ( $8 \mathrm{~mm}$. long).

Branchlets straight, fuscous when dry; third year's growth $4 \mathrm{~mm}$. in diameter, pubescent, smooth, inconspicuously longitudinally rimulose, the lenticels lacking, the leaf-scars semi-orbicular; second year's growth densely pubescent; current year's growth subterete or angular, $2.5 \mathrm{~mm}$. in diameter, fuscously and densely pubescent, the terminal buds naked, small, pubescent. Leaves occurring even on the fourth year's growth, 3-10, sometimes up to $15 \mathrm{~mm}$. apart; stipules callose, deltoid, falcate, very acute, pubescent at the base; petioles 7-10 mm. long, one-tenth to one-sixth the length of the lamina, pubescent, the distal half narrowly winged by the decurrent leaf-base, canaliculate above; lamina thick-coriaceous, cinereous-olivaceous when dry, shiny above, dusty brown beneath, elliptic, very rarely lanceolate or ovate-elliptic, $5-8 \mathrm{~cm}$. long, $1.5-3.5 \mathrm{~cm}$. wide; obtuse or cuneate at the base; very shortly and gradually acuminate at the apex, the acumen broad-deltoid, 5-12 mm. long, often nigrescent; margin crenate-serrate, slightly recurvate when dry; midrib impressed and pubescent above, elevated beneath, the lateral nerves 7 or 8 pairs, obscure above, evident beneath, the reticulation of the veinlets sometimes evident beneath. Inflorescence fasciculate, axillary, on the second year's growth, fascicle 2-5-flowered, the bracts ovate-reniform, mucronate, or cuspidate, ciliate; flowers 4-merous. Pistillate flowers: individual branches of the fascicles uniflorous, the pedicels 6-8 $\mathrm{mm}$. long, pubescent, with 2 submedian longdeltoid pubescent prophylla; calyx patelliform, $3 \mathrm{~mm}$. across, the lobes shallow, rounded, $0.5 \mathrm{~mm}$. long, $1.5 \mathrm{~mm}$. wide, rugose, very sparsely and minutely puberulent, ciliate; corolla rotate, $8 \mathrm{~mm}$. in diameter, the petals $3 \mathrm{~mm}$. long, $2 \mathrm{~mm}$. wide, the apical portion ciliate; staminodes slightly shorter than the petals, the sterile anthers sagittate; ovary large, ovoid, $3 \mathrm{~mm}$. long, $2.5 \mathrm{~mm}$. wide, the apical end truncate, the stigma discoid. Staminate flowers not seen. Fruit subglobose, $8 \mathrm{~mm}$. long, $10 \mathrm{~mm}$. in diameter, the stigma flat, orbicular, $2 \mathrm{~mm}$. across, the persistent calyx explanate, orbicular, $3 \mathrm{~mm}$. across, ciliate; the fruiting pedicels $8 \mathrm{~mm}$. long, the exocarp thin, the mesocarp fleshy, abundant. Pyrenes 4 , oblong in outline, $6.5 \mathrm{~mm}$. long, $5.5 \mathrm{~mm}$. wide, rugose, reticulately striate, flattened and broadly depressed on the dorsal surface, the endocarp woody. 
CHINA: Kwangtung: Sin-fung, Y. W. Taam 271 (A). Kwangsi : Seh-feng-dar-shan, R. C. Ching 8082 (Isotypes LU, NY; fragments, A); Sup-man-ta-shan, H. Y. Liang 69851 (A); Shap-man-taai-shan, W.T. Tsang 22073 (A). H a in a n : Ba-tung, S. K. Lau 28238 (A).

Ilex nanningensis was first described from a specimen collected in the high mountains south of Nanning, Kwangsi Province. From the material at hand, it appears to be endemic to the mountain range between Kwangsi and Indo-China. There it grows as a big tree in woods or mixed forests at an altitude of $600 \mathrm{~m}$. The fragrant yellow flowers appear in April and the fruit turns bright red in October.

It should be noticed that the Kwangsi localities all refer to one mountain range, the name of which is variously transliterated by persons speaking different dialects. The preferred spelling is "Shih-wan-ta-shan."

The large fruit, the big rugose pyrenes, and the form and shape of the leaves of this species ally it closely to Ilex subficoidea S. Y. Hu, which differs in having glabrous branchlets and leaves.

50. Ilex latifolia Thunb., Fl. Jap. 79. 1784; Willd. Sp. Pl. 1(2): 708 1797; Persoon Syst. Veg. 174, 1797, et Syn. Pl. 1: 151. 1805; Poir. in Lam. Encycl. Suppl. 3: 66. 1813; Roem. \& Schult., Syst. 3: 488. 1818; DC. Prodr. 2: 16. 1825; Spreng. Syst. 1: 494. 1825; Dietr. Syn. Pl. 1: 556. 1839; Sieb. \& Zucc. in Abh. Bay. Ak. Wiss. IV, 2 : 148 (Fl. Jap.). 1845; Regel in Gartenfl. 13: 38. 1864; Hook. in Bot. Mag. 22: pl. 5597. 1866; Miq. in Ann. Mus. Bot. Lugd.-Bat. 3: 105. 1867; Maxim. in Mém. Acad. St. Pétersb. VII, 29(3): 29 , 43, pl. 1, fig. 2. 1881; Loes. in Nov. Act. Acad. Caes. Leop.-Carol. Nat. Cur. 78: 289 (Monog. Aquif. 1: 289). 1901; Moore, Holly Yew Box 127. 1908; Chung in Mem. Sci. Soc. China 1: 140. 1924; Chien in Contr. Biol. Lab. Sci. Soc. China 3(1): 58. 1927; Rehd. in Jour. Arnold Arb. 8: 157. 1927; Hand.-Mzt., Symb. Sin. 7: 656. 1933; Belval, Mus. Heud. Nat. Bot. Chin. 2: 21. 1933; Kia, Pl. Sin. Ill. 491, fig. 830. 1937; Chen, Ill. Man. China Trees 660, fig. 552. 1937.

Ilex macrophylla Blume Bijdr. 1150. 1825; Dietr., Syn. P1. 1: 556. 1839;

Walp. Rep. 1: 540. 1842.

Ilex tarajo Hort. Göpp. in Gartenfl. 3: 325. 1854.

Ilex terago Anon. in Gard. Chron. 1859: 508, 972. 1859.

A very large, entirely glabrous evergreen tree up to $20 \mathrm{~m}$. high, trunk $60 \mathrm{~cm}$. in diameter (ex Ching) with large thick-coriaceous oblong serrate leaves, axillary paniculate staminate and racemose pistillate inflorescences, globose fruit with thick exocarp, and 4 bony wrinkled pyrenes.

Branchlets straight, stout, ochraceous or brown; second year's growth $5-7 \mathrm{~mm}$. in diameter, longitudinally plicate, often rimose, the lenticels lacking or sparse, the leaf-scars elevated, broad-deltoid or semi-orbicular; current year's growth 4-5 $\mathrm{mm}$. in diameter, striate, sulcate and angular, smooth and glabrous, tuberculate under a lens. Leaves occurring even on the third year's growth, $8-17 \mathrm{~mm}$. apart; stipules very minute and 
callose, broad-deltoid, acute; petioles thick, short, rugose, 15-20 mm. long, one-eighth to one-seventh the length of the lamina, $3 \mathrm{~mm}$. in diameter, subcylindrical, slightly impressed above, glabrous; lamina thick-coriaceous, olivaceous, shiny above, opaque beneath, oblong or ovate-oblong, 8-17 $\mathrm{cm}$. long, $4.5-7.5 \mathrm{~cm}$. wide; base rounded; apex obtuse or very shortly acuminate, the acumen 3-6 $\mathrm{mm}$. long; margin serrate, the teeth nigrescent; midrib impressed above, strongly elevated beneath, the lateral nerves 15-17 pairs, obscure on both surfaces. Inflorescences pseudopaniculate, sessile, axillary, on the second year's growth; rachis $1-2 \mathrm{~cm}$. long, 2-3 mm. thick, the bud scales persistent, imbricate, the outer ones cartilaginous, rounded, ca. $3 \mathrm{~mm}$. long, $5 \mathrm{~mm}$. wide, the inner ones membranous, larger; flowers 4-merous. Staminate inflorescence: individual branches of the pseudopanicles 3-9-flowered, cymose, the bracts ovate, 5-7 mm. long, 3-5 $\mathrm{mm}$. wide, the peduncles $2 \mathrm{~mm}$. long, the bracteoles hyaline, ovate or lanceolate, 2-3 $\mathrm{mm}$. long, the pedicels $6-8 \mathrm{~mm}$. long, with 1 or 2 sheathlike, broad-deltoid basal prophylla; calyx subcupuliform, $3.5 \mathrm{~mm}$. in diameter, shallowly 4-lobed, the lobes rounded, ca. $0.75 \mathrm{~mm}$. long, 1.75 $\mathrm{mm}$. wide; corolla rotate, reflexed, ca. $9 \mathrm{~mm}$. across, the petals ovate-oblong, ca. $3.5 \mathrm{~mm}$. long, $2.5 \mathrm{~mm}$. wide, one-eighth connate at the base; stamens equaling the petals in length, the anthers ovoid-oblong, ca. $1.25 \mathrm{~mm}$. long, the filament twice as long; rudimentary ovary subglobose, ca. $1 \mathrm{~mm}$. in diameter, the apex introrse, 4-lobed. Pistillate inflorescence: individual branches of the pseudopanicles 1-3-flowered, the peduncles of the 3-flowered cymes $2 \mathrm{~mm}$. long, the pedicels of the uniflorous ones $5-8 \mathrm{~mm}$. long, with 1 or 2 basal prophylla; calyx patelliform, ca. $3 \mathrm{~mm}$. across; corolla erect, ca. $5 \mathrm{~mm}$. across, the petals ovate, ca. $3 \mathrm{~mm}$. long, $2 \mathrm{~mm}$. wide; staminodes one-third the length of the petals, the sterile anthers minute, ovate; ovary ovoid, ca. $2 \mathrm{~mm}$. wide at the base, the stigma 4-lobed discoid. Fruit globose, ca. $7 \mathrm{~mm}$. in diameter, brown or reddish when dry, the stigma thinly discoid, explanate, the exocarp thick, smooth, minutely tuberculate under a lens, the persistent calyx explanate, 3-4 mm. across. Pyrenes 4, oblong-elliptic in outline, ca. $5 \mathrm{~mm}$. long, $2.5 \mathrm{~mm}$. wide, irregularly wrinkled and pitted, the dorsal surface with 3 distinct longitudinal ridges, the endocarps bony.

CHINA: Ki angsu: I-shing, Ching \& Tso 630 (A) ; K. Ling 12377 (NY). Anhwei: Chu-wha-shan, R. C. Ching 2626 (A, LU); Chi-men, R. C. Ching 3155 (A); Wang-shan, A. N. Steward 7140 (A, US). Ch e k ia ng: Tien-tai-shan, R. C. Ching 1436 (A, US); Chen-chion, R. C. Ching 1780 (A, LU, US); Tien-mo-shan, R. C. Ching 5113 (A); Ning-po, E. Faber (NY). Fukien: Dunn 2474 (A).

JAPAN: Honshu, R. K. Beattie \& Y. Kurihara 1014 (A); U. Faurie 6122 (A); Nagasaki, Maximowicz in 1863 (G, NY); Yokohama, Maximowicz in 1862 (NY); K. Sakurai in 1901 (A), in 1913 (A) ; Hondo, K. Shiota 7421 (A); Siebold (A); Mt. Kirishima, E. H. Wilson 6253 (A), 10340 (A) ; Tokyo, E. H. Wilson 6378 (A); C. S. Sargent (A); K. Watanabe in 1889 (G).

CULTIVATED: I have seen specimens from various botanical gardens of Europe and America. 
Ilex latifolia was first recorded from Japan. Specimens have been collected from a few of the coastal provinces of China. It has been reported as common in central Chekiang Province. It grows in woods at an altitude of 100-700 m. and the flowers, which appear in April, are yellowish green. The fruits turn red in October.

In Chekiang and Fukien provinces the wood of this species is used for rolling-pins and other turned work. The bark is used for making birdlime and the leaves are used as a substitute for tea.

The large thick glossy leaves of Ilex latifolia are very characteristic. There is no other species of Chinese Ilex that has the like. In the structure of the inflorescence and flowers it is closely related to Ilex denticulata (Wall.) Wight, which differs in having smaller leaves and fruits.

\section{Ilex suzukii, sp. nov.}

Frutex; ramulis glabris; foliis coriaceis, ellipticis, $2.5-4 \mathrm{~cm}$. longis, $1.5-2.2 \mathrm{~cm}$. latis, integris, basi acutis vel cuneatis, apice breviter acuminatis vel obtusis, acuminibus $3 \mathrm{~mm}$. longis, costa supra plana, subtus elevata, nervis lateralibus utrinque 5 vel 6 , subtus prominentibus; inflorescentiis fructiferis paucifasciculatis, axillaribus, pedicellis $4 \mathrm{~mm}$. longis, glabris; fructibus globosis, $5 \mathrm{~mm}$. diametro, stigmate umbilicato, pyrenis 4, $3 \mathrm{~mm}$. longis, $2 \mathrm{~mm}$. latis, palmatim striatis, esulcatis, lignescentibus.

An evergreen shrub with glabrous branches, small elliptic entire leaves, fasciculate infructescences, globose fruit with a navel-like stigma and palmately striate, esulcate pyrenes.

Branchlets nigrescent, glabrous; third year's growth terete, $2.5 \mathrm{~mm}$. in diameter, the lenticels lacking, the leaf-scars semi-orbicular, slightly elevated; current year's growth $1.5 \mathrm{~mm}$. in diameter, longitudinally ridged, angular, the axillary buds large, globose, the terminal bud acute-conic, glabrous, the scales densely ciliate. Leaves occurring even on the fourth year's growth, 2-6 mm. apart; stipules very minute, often obscure; petioles $5-7 \mathrm{~mm}$. long, one-eighth to one-fifth as long as the lamina, narrowly canaliculate above, glabrous; lamina coriaceous, brunneous-olivaceous when dry, somewhat shiny above, opaque beneath, elliptic, $2.5-4 \mathrm{~cm}$. long, $1.5-2.2 \mathrm{~cm}$. wide, acute or cuneate at the base, obtuse or very shortly acuminate at the apex, the acumen $3 \mathrm{~mm}$. long; margin entire; midrib plane above, slightly elevated beneath, the lateral nerves 5 or 6 pairs, obscure above, prominent beneath, the reticulation of the veinlets obscure above, prominent beneath. Flowers not seen. Infructescences paucifasciculate, axillary, on the second year's growth, the fascicles with 2 or 3 fruits, the individual branches of the fascicles uniflorous, the bracts suborbicular or ovate, ciliate; fruiting pedicels $4 \mathrm{~mm}$. long, glabrous, with 2 minute deltoid ciliate prophylla at the base. Fruit globose, $5 \mathrm{~mm}$. in diameter, castaneous, smooth and shiny when dry, the persistent calyx explanate, orbicular in outline, $2.5 \mathrm{~mm}$. in diameter, shallowly 4-lobed, the lobes rounded, ciliate, the stigma navel-like, 4-lobed. Pyrenes 4, oblongobovate in outline, the ends obtuse, $3 \mathrm{~mm}$. long, $2 \mathrm{~mm}$. wide, palmately striate and esulcate, the striae slightly elevated, the endocarp woody. 

TU).

CHINA: Taiwan: Taheizan, S. Suzuki in 1928 (туре, A; Isотуре,

The entire leaves, the prominent venation, the striate and esulcate pyrenes of Ilex suzukii, indicate close relationship with Ilex mertensii Maxim. However, the latter species has large thick-coriaceous leaves $5-9(-16) \mathrm{cm}$. long and, also, large fruits $8-9 \mathrm{~mm}$. in diameter. This species has been mistakenly identified as Ilex hanceana Maxim. in the past. This last species can readily be distinguished by the pubescent branchlets, the short petioles $(2-5 \mathrm{~mm}$. long), the obscure veins, the fruiting pedicels $1-1.5 \mathrm{~mm}$. long, and the smaller fruits.

52. Ilex denticulata Wall. List 4333. 1830, nom. nud.; Wight, Ill. Ind. Bot. 2: 147, pl. 149. 1850; Beddome, Fl. Sylv. 1: 142. 1869; Hooker f., Fl. Br. Ind. 1: 600. 1875; Maxim. in Mém. Acad. St. Pétersb. VII, 29(3) : 29. 1881; Loes. in Nov. Act. Acad. Caes. Leop.Carol. Nat. Cur. 78: 320 (Monog. Aquif. 1: 320). 1901.

Ile.x nilagirica Miq. ex Hook. f., 1 . c.

A glabrous evergreen tree with coriaceous ovate-elliptic, elliptic, or oblong leaves, obtuse or shortly acuminate apices, serrate margins, pseudopaniculate staminate and pseudoracemose pistillate inflorescences, globose fruits, and stony, irregularly striate, sulcate and wrinkled pyrenes.

Branchlets straight, glabrous, brunneous, second year's growth subterete, 3-5 mm. in diameter, minutely rimulose, the lenticels lacking, the leaf-scars deltoid, not elevated; current year's growth subangular, striate, $3 \mathrm{~mm}$. in diameter; terminal buds narrowly conic, the scales cartilaginous, eciliate. Leaves occurring also on second year's growth, 1-2 cm. apart; stipules lacking or very minute, callose and nigrescent; petioles rather stout, 10-13 mm. long, one-fifth to one-seventh the length of the lamina, glabrous, narrowly or not at all sulcate above, rugose beneath; lamina coriaceous, olivaceous or cinereous-olivaceous, ovate-elliptic or ellipticoblong, 5-10 cm. long, $2.5-3.7 \mathrm{~cm}$. wide; base obtuse or cuneate; apex very shortly and abruptly acuminate or obtuse, the acumen 3-8 $\mathrm{mm}$. long; margin densely and often irregularly denticulate-serrate, the teeth nigrescently apiculate; midrib glabrous, narrowly impressed above, elevated beneath, the lateral nerves 6-9 pairs, obscure above, prominent beneath, the reticulations obscure above, evident beneath. Staminate inflorescences: pseudo-paniculate, axillary, sessile, only on the second year's growth, the rachis 4-14 mm. long, the individual branches 1-3flowered, the bracts obovate, acute, $4 \mathrm{~mm}$. long, 2-5 mm. wide; 3-flowered cymes with peduncles $2 \mathrm{~mm}$. long, the pedicels $2-3 \mathrm{~mm}$. long, the uniflowered pedicels $5 \mathrm{~mm}$. long, glabrous, with 2 submedian deltoid prophylla; flowers 4-merous; calyx patelliform, $2.5 \mathrm{~mm}$. across, glabrous, the lobes deltoid, ca. $0.57 \mathrm{~mm}$. long, $1 \mathrm{~mm}$. wide, acute or acuminate, entire, eciliate; corolla rotate, $7 \mathrm{~mm}$. across, the petals oblong, reflex, $3 \mathrm{~mm}$. long, 1.5 $\mathrm{mm}$. wide, one-tenth connate at the base; stamens equaling the petals in length, the anthers small, ovoid, ca. $0.75 \mathrm{~mm}$. long; rudimentary ovary globose, the apex rounded and slightly depressed. Infructescences fascicu- 
late or pseudoracemose, the central axis 5-10 mm. long, the individual branches uniflorous, the fruiting pedicels $6-10 \mathrm{~mm}$. long, glabrous or sparsely puberulous. Fruits globose or depressed globose, 6-7 $\mathrm{mm}$. in diameter, brown and smooth, the persistent calyx explanate, $3 \mathrm{~mm}$. in diameter, the stigma navel-like, often depressed, 4-lobed. Pyrenes 4, oblong or elliptic in outline, irregularly striate, sulcate, wrinkled and pitted, ca. $4-5 \mathrm{~mm}$. long, $3 \mathrm{~mm}$. wide, the endocarp stony.

CHINA: Yunnan: Fo-hai, C. W. Wang 77406 (A).

INDIA: Madras, D. Brandis 666; Nilghiri, Ed. Hohenacker 1455 (A), 1456 (fragment, A); Culgherris, Perrottet (A); Nilghiri Hills, E. H. Wilson; Wight 437 (Isотуре, G, NY), 438 (NY), 490 (fragment, A).

Ilex denticulata was first recorded from Nilghiri Hills of India as a large tree up to $12 \mathrm{~m}$. high. Specimens collected from the type locality vary in the degree of their pubescence. Some of them (Wight 437, 490; Hohenacker 1455) are entirely glabrous, and others (Hohenacker 1456) are with slightly pubescent pedicels. In the form, size, and margin of the leaves, pubescence of the inflorescences, size of the fruit, and number and nature of the pyrenes, the Chinese specimens collected from southwestern Yunnan match the Indian type very well, with the exception of the more pubescent pedicels. In Yunnan, the plant grows to be a big tree up to $12 \mathrm{~m}$. high. It occurs in mixed forests at an altitude of $2000 \mathrm{~m}$.

In its irregularly wrinkled and pitted stony pyrenes and the navel-like stigma, Ilex denticulata is closely related to Ilex latifolia Thunb., but the latter has thick-coriaceous larger $(8-17 \mathrm{~cm}$. long, $4.5-7.5 \mathrm{~cm}$. wide) leaves and 3-9-flowered individual branches in the staminate pseudopanicles. The leaves of Ilex denticulata resemble superficially those of Ilex chieniana $\mathrm{S}$. Y. Hu, but the latter has palmately striate and sulcate pyrenes, thickly discoid or capitate stigmata, and ciliate calyx-lobes.

53. Ilex graciliflora Champ. in Jour. Bot. Kew Gard. Miscel. 4: 328. 1852; Walp. Ann. 4: 429. 1857; Benth. Fl. Hongk. 65. 1861; Maxim. in Mém. Acad. Sci. St. Pétersb. VII, 29(3): 43. 1881; Forbes \& Hemsl. in Jour. Linn. Soc. Bot. 1: 116. 1886; Loes. in Nov. Act. Acad. Caes. Leop.-Carol. Nat. Cur. 78: 338 (Monog. Aquif. 1: 338). 1901; Dunn \& Tutcher in Kew Bull. Misc. Inf. Add. Ser. 10: 60. 1912.

An evergreen tree up to 6-9 $\mathrm{m}$. high with rather stout branchlets, obovate or oblong-elliptic leaves, minutely and loosely serrulate or subentire leaves, fasciculate inflorescences, globose fruit with plane and thin-discoid stigmata and 4 wrinkled and rugose, irregularly striate-sulcate pyrenes.

Branchlets subterete, castaneous or rarely brunneous when dry; third year's growth 3-4 mm. in diameter, longitudinally rimulose, the lenticels lacking, the leaf-scars deltoid, not elevated; second year's growth $2.5 \mathrm{~mm}$. in diameter, longitudinally plicate, rugose, glabrous; current year's growth $1.8-2 \mathrm{~mm}$. in diameter, angular, longitudinally ridged, minutely and sparsely puberulous, glabrescent or glabrous, the terminal bud conic, acute, pubescent. Leaves occurring even on the third year's growth, 5-20 
$\mathrm{mm}$. apart; stipules minute, often hidden; petioles $10-15 \mathrm{~mm}$. long, onefifth to one-half the length of the lamina, glabrous or minutely puberulous above, narrowly and deeply canaliculate, the distal half winged by the decurrent leaf-base; lamina thickly coriaceous, olivaceous-brunneous when dry, shiny above, less so beneath, obovate- or oblong-elliptic, $2-7.5 \mathrm{~cm}$. long, $1.5-3.5 \mathrm{~cm}$. wide; obtuse or acute at the base; obtuse, rarely acute or retuse at the apex; margin minutely and remotely serrulate or rarely subentire; midrib impressed and glabrous above, elevated beneath, the lateral nerves 5-7 pairs, obscure above, prominent beneath, loosely reticulate, the veinlets evident on the lower surface. Inflorescences fasciculate, axillary, on last year's growth, with abortive terminal buds, the bracts ovate-deltoid, acute or tricuspidate, puberulous; flowers 4-merous. Staminate flower: individual branches of the fascicles 3-flowered; peduncles shorter than the pedicels, 1-2 $\mathrm{mm}$. long, the pedicels $3-6 \mathrm{~mm}$. long, both sparsely puberulent or glabrescent, the prophylla 1 or 2 , basal or subbasal; calyx patelliform, $2 \mathrm{~mm}$. across, shallowly 4-lobed, the lobes deltoid, obtuse or rounded, ciliate; corolla rotate, reflexed, $6 \mathrm{~mm}$. across, the petals oblong, $2.5 \mathrm{~mm}$. long, one-eighth connate at the base, ciliate; stamens shorter than the petals, the anthers oblong-ovoid; rudimentary ovary subglobose-ovoid, obtuse at the apex, inconspicuously 4-lobed. Pistillate flower: individual branches of the fascicles uniflorous, the bracts small, ovate, cuspidate or tricuspidate; pedicels $4 \mathrm{~mm}$. long (after fruiting 6 $\mathrm{mm}$. long) with 2 basal prophylla; calyx as in the staminate flowers; corolla choripetalous, the petals oblong-obovate, $2.5 \mathrm{~mm}$. long; staminodes two-thirds as long as the petals, the sterile anthers sagittate; ovary globoseovoid, $1.5 \mathrm{~mm}$. in diameter, the stigma discoid. Fruit globose, 5-6 mm. in diameter, the persistent calyx explanate, $2 \mathrm{~mm}$. in diameter, suborbicular in outline, ciliate, the stigma plane, thin-discoid. Pyrenes 4, suborbicular in outline, the ends rounded, $4 \mathrm{~mm}$. long, $3 \mathrm{~mm}$. wide, wrinkled and rugose, irregularly striate-sulcate, the striae reticulate, the back shallowly impressed, the endocarp woody.

CHINA: Hongkong: Champion (fragment of type, A); Wu-kautin, W. Y. Chun 5039 (A); Ford (staminate flowers, A, NY; fruiting branches, A) ; Lamont (B); Lugard Road, Y.W. Taam 1603 (A); Wongneichong, $Y$. W. Taam 2013 (A); along Bride Valley, Y. Tsiang 49 (A); Peak, $Y$. Tsiang 256 (A, NY); Mt. Victoria, $W$. J. Tutcher (ex Fierb. Hongkong no. 10213) (A); C. Wright (NY, US). L a n t a o I sl and: C. L. Tso 20193 (A).

Ilex graciliflora is endemic to Hongkong and the near-by islands, where it can be found growing in woods or in thickets as a tree 6-9 m. high. The white flowers appear in April. The red fruits persist long on the tree, even into February or later of the following year.

The glabrescent branchlets, the coriaceous leaves, the fasciculate inflorescences, and the wrinkled and rugose pyrenes of Ilex graciliflora indicate close relationship between this species and Ilex ficoidea Hemsl., which differs in having leaves with caudate apices, 9 or 10 indistinct parallel lateral nerves, median or submedian prophylla, and very shor $\hat{\imath}$ fruiting pedicels (2-3 $\mathrm{mm}$. long). 


\section{Ilex tsangii, sp. nov.}

Arbor glaberrima; ramulis nigrescentibus; foliis subcoriaceis, ellipticis vel ovato-ellipticis, $5-8 \mathrm{~cm}$. longis, $2-3 \mathrm{~cm}$. latis, crenulatis vel subintegris, basi acutis vel cuneatis, apice acuminatis, acuminibus $10-15 \mathrm{~mm}$. longis, costa supra impressa, subtus elevata, nervis lateralibus, utrinque 6-8, supra obscuris, subtus evidentibus; inflorescentiis fructiferis fasciculatis, axillaribus; pedicellis 10-12 mm. longis; fructibus depresso-globosis, 5 $\mathrm{mm}$. longis, $6 \mathrm{~mm}$. diametro; calycibus persistentibus $1.5 \mathrm{~mm}$. diametro, stigmate minute discoideo; pyrenis $4,4 \mathrm{~mm}$. longis, $3 \mathrm{~mm}$. latis, striatis, rugosis et sulcatis, endocarpio coriaceo.

An entirely glabrous evergreen tree up to $8 \mathrm{~m}$. high with nigrescent branchlets, elliptic leaves with minutely crenulate or subentire margin, long-acuminate apices, fasciculate infructescences, slender fruiting pedicels 10-12 mm. long, and rather small globose fruits.

Branchlets slender, subterete, glabrous; third year's growth $2 \mathrm{~mm}$. in diameter, sparsely and minutely rimulose, the lenticels lacking, the leafscars elevated; current year's growth $1-1.5 \mathrm{~mm}$. in diameter, angular, the terminal bud narrowly conic, acute, glabrous. Leaves occurring even on the third year's growth, 5-12 mm. apart; stipules very minute, often obscure; petioles slender, $10-16 \mathrm{~mm}$. long, one-sixth to one-fifth the length of the lamina, narrowly canaliculate above; lamina subcoriaceous, brunneous-olivaceous when dry, ovate-elliptic or elliptic, 5-8 cm. long, 2-3 $\mathrm{cm}$. wide; acute or cuneate at the base; acuminate at the apex, the acumen $10-15 \mathrm{~mm}$. long; margin remotely and inconspicuously crenulate or subentire; midrib narrowly and shallowly impressed above, elevated beneath, the lateral nerves $6-8$ pairs, obscure above, evident beneath. Flowers not seen. Infructescences fasciculate, axillary, on second year's growth, fascicles with 2-4 fruits, the fruiting pedicels slender, $10-12 \mathrm{~mm}$. long with 2 minute ciliate basal prophylla. Fruit depressed globose, $5 \mathrm{~mm}$. long, $6 \mathrm{~mm}$. in diameter, when dry black and rugose, the persistent calyx minute, 1.5 $\mathrm{mm}$. in diameter, the stigma minute, thin-discoid. Pyrenes 4 , obovate in outline, $4 \mathrm{~mm}$. long, $3 \mathrm{~mm}$. wide, one end slightly pointed, reticulately striate, irregularly rugose and sulcate, the endocarp thick-coriaceous (described from immature fruit).

CHINA: Kwangtung: Ta-pu, W. T. Tsang 21232 (тype A; LU).

This species is endemic to northeastern Kwangtung, where it is a common tree in woods or thickets. The fruit has been reported as yellow in July. The species is closely related to Ilex graciliflora Champ., which differs in having thick-coriaceous leaves with obtuse apices.

55. Ilex chingiana $\mathrm{Hu} \&$ Tang in Bull. Fan. Mem. Biol. Bot. 9: 252 . 1940.

A glabrous evergreen tree up to $12 \mathrm{~m}$. high with large $(11-15 \mathrm{~cm}$. long) coriaceous, oblong-elliptic, remotely serrate and acuminate leaves, very large $(15 \mathrm{~mm}$. in diameter $)$ globose fruit, and 4 large wrinkled and pitted pyrenes. 
Branchlets robust, straight, glabrous, castaneous when dry; third year's growth $3.5-4.5 \mathrm{~mm}$. in diameter, transversely plicate-rugose when dry, the lenticels.lacking, the leaf-scars semi-orbicular; second year's growth longitudinally plicate-rugose, subterete, $3-4 \mathrm{~mm}$. in diameter; current year's growth angular, longitudinally striate, $2.5-3 \mathrm{~mm}$. in diameter, the terminal buds small, conical, the scales glabrous, ciliate, the axillary buds globose, glabrous. Leaves occurring even on the third year's growth, 5-20 mm. apart; stipules obscure; petioles 10-15 mm. long, one-tenth to one-seventh the length of the lamina, glabrous, rugose, narrowly canaliculate above; lamina thick-coriaceous, brunneous-olivaceous when dry, glabrous, rather opaque on both surfaces, oblong-elliptic or very rarely oblanceolate, 11-14 $\mathrm{cm}$. long, 4-5 cm. wide; base obtuse, rarely rounded or cuneate; apex acuminate, the acumen $7-12 \mathrm{~mm}$. long; margin remotely serrate; midrib impressed above, sparsely and minutely puberulent, very prominent and elevated beneath, the lateral nerves $8-12$ pairs, slightly elevated above, evident beneath, the reticulation of the veinlets conspicuous above, less so beneath. Infructescence a small fascicle, usually only one fruit maturing; bracts cartilaginous, glabrous, the apex acute, callose, the basal appendage stipule-like, acute, ciliate; fruiting pedicels $2-4 \mathrm{~mm}$. long, minutely and sparsely puberulent when young, glabrescent later, with 2 sub-basal prophylla; persistent calyx explanate, orbicular in outline, $3.5 \mathrm{~mm}$. in diameter, inconspicuously 4-lobed, the lobes rounded, sparsely puberulent and ciliate; fruits globose, $15 \mathrm{~mm}$. in diameter, the stigma navel-like, orbicular in outline when young, later appearing quadrangular, 4-5 mm. in diameter. Pyrenes 4, obovate in outline, $10-12 \mathrm{~mm}$. long, 6-8 $\mathrm{mm}$. wide at the base, reticulately striate, sulcate, wrinkled and pitted, the back flattened and broadly impressed, the endocarp stony.

CHINA: Kweichow: San-hoa, Y. Tsiang 6396 (NY). Kwangs i : Lu-chen-hsien, R. C. Ching 6011 (Isotype, A, US), Chuen-yuen, T. S. Tsoong (= Z. S. Chung) 82033 (A); Ping-nan-hsien, C. Wang 40344 (A), 40388 (A).

Ilex chingiana is endemic to Kwangsi Province, where it grows as a tree in mixed forests. Specimens collected in June show very young fruits. This may indicate that it flowers in May. Those collected in November have large red fruits.

Because of the large leaves with remotely serrate margins, the large fruit with navel-like stigmas, and the large reticulately striate, sulcate, wrinkled and pitted pyrenes, this Kwangsi species is closely related to the Hainan species Ilex nuculicava $\mathrm{Hu}$. The latter species has puberulent branchlets and petioles, pseudoracemose infructescences with smaller fruits, and longer fruiting pedicels.

The infructescences of the material at hand appear solitary, but on careful examination the paucifasciculate nature can easily be detected, for the scars of the falling flowers and bracts are evident.

Only fruiting material has been available for this study. The size of the fruits on these specimens varies considerably with seasonal variation. 
As the fruit matures, the mesocarp increases in volume and becomes fleshy. As the fruits enlarge, the tissue of the exocarp next to the stigmatic lobes is torn. When dry, this rent and discolored tissue gives the stigmata a starlike outline. This character, the star-like stigma, is characteristic for this species and a diagnostic character.

When the ripe fleshy fruit is pressed, the exocarp breaks and the fruit flattens. On herbarium specimens such pressed fruits appear much larger than their actual size. This is plainly the case with C. Wang 40344 and 40388 .

55a. Ilex chingiana var. puberula, var. nov.

Arbor parva; ramulis glabris, castaneis, gemmis terminalibus pubescentibus; foliis oblanceolatis, $7-12 \mathrm{~cm}$. longis, $3 \mathrm{~cm}$. latis, serratis, basi cuneatis, apice acuminatis, acuminibus $8-14 \mathrm{~mm}$. longis, costa et petiole puberulis; fructibus globosis, $11 \mathrm{~mm}$. diametro, pedicellis pubescentibus, $3 \mathrm{~mm}$. longis.

CHINA: Kwangsi: Ling-wun, S. K. Lau 28662 (type, A).

This variety grows in mixed forest as a tree $10 \mathrm{~m}$. high with a trunk $30 \mathrm{~cm}$. in diameter.

The variety differs from the typical Ilex chingiana in that it has narrower predominantly oblanceolate leaves with cuneate bases and puberulent terminal buds and petioles.

56. Hex uraiensis Yamamoto in Jour. Soc. Trop. Agric. Taiwan 4: 486. 1932.

Ilex glomeratiflora sensu Yamamoto, Suppl. Ic. P1. Form. 1: 32, fig. 13. 1925, non Hayata.

An evergreen tree up to $25 \mathrm{~m}$. high, with minutely puberulous or glabrescent branches, elliptic or obovate-elliptic leaves, remotely crenate or serrate margins, abruptly and shortly acuminate apices, fasciculate inflorescences, fruiting pedicels $6-8 \mathrm{~mm}$. long, large globose fruit, and irregularly striate and wrinkled stony pyrenes.

Branchlets subterete, cinereous or rarely nigrescent when dry; third year's growth $3 \mathrm{~mm}$. in diameter, longitudinally rimulose, the lenticels lacking, the leaf-scars crescent-shaped, slightly elevated; current year's growth 1-2 $\mathrm{mm}$. in diameter, longitudinally ridged, minutely puberulous or glabrescent, the terminal buds ovoid, pubescent. Leaves occurring also on second year's growth, rarely on the third year's growth, 5-12 mm. apart; stipules minute, deltoid, persistent; petioles $6-10 \mathrm{~mm}$. long, onetenth to one-sixth the length of the lamina, the distal half winged by the decurrent leaf-base, narrowly canaliculate above; lamina thinly coriaceous, olivaceous when dry, shiny above, opaque beneath, elliptic or obovateelliptic, 3.5-10 cm. long, $1.2-3.5 \mathrm{~cm}$. wide, cuneate at the base, shortly and abruptly acuminate at the apex, the acumen $3-8 \mathrm{~mm}$. long, the very tip obtuse, the margin remotely crenate or serrate; midrib very slightly impressed above, elevated beneath, the lateral nerves $8-9$ pairs, prominent on both surfaces, the reticulation of the veinlets prominent on both sur- 
faces. Inflorescences fasciculate, axillary on the second or even the third year's growth, the individual branches of the fascicles uniflorous, the bracts suborbicular, ciliate; flowers 4-merous. Staminate flowers: pedicels 3-5 $\mathrm{mm}$. long, minutely puberulous, with 2 minute ciliate prophylla at the base; calyx patelliform, $2 \mathrm{~mm}$. in diameter, shallowly 4-lobed, the lobes rounded, ciliate; corolla rotate, $7-8 \mathrm{~mm}$. in diameter, the petals obovateoblong, 3-5 mm. long, $2.5 \mathrm{~mm}$. wide, ciliate, slightly connate at the base; stamens longer than the petals, the anthers oblong-ovoid, $1.25 \mathrm{~mm}$. long; rudimentary ovary subglobose, the apex rounded or slightly depressed. Pistillate flowers not seen. Infructescences fasciculate, the bracts oblongovate, puberulous, and ciliate, with 2 acute stipule-like appendages; fruiting pedicels slender, 6-8 mm. long, pubescent, with 2 sub-basal, deltoid, acute, puberulous, ciliate prophylla. Fruit globose, large, $10-11 \mathrm{~mm}$. in diameter, the persistent calyx suborbicular in outline, $2 \mathrm{~mm}$. in diameter, ciliate, the stigma navel-like, $2.5 \mathrm{~mm}$. in diameter. Pyrenes 4 , oblong in outline, the ends obtuse, $7-8 \mathrm{~mm}$. long, $4.5 \mathrm{~mm}$. wide, irregularly striate and wrinkled, the back flattened and depressed, the endocarp stony.

CHINA: T a iw an : R. Kanehira \& S. Sasaki in 1916 (photo of TYPE, TU) ; Y. Shimada (TU); Sozan, E. H. Wilson 10288 (A, NY, US), 11213 (A, US) ; Sirin, K. Odashima (Taihoku Imp. Univ. Herb. no. 17751) (A, NY, US) ; Kiirun (Taihoku Imp. Univ. Herb. no. 17797) (A, NY, US); Herb. Univ. Imp. Taihoku no. 2872 (TU).

This species is endemic to Taiwan, where it grows as a common tree up to $25 \mathrm{~m}$. high with a trunk $0.5-1 \mathrm{~m}$. in diameter. The white flowers appear in April, and the mature red fruit persists on the tree during the winter months.

The slender fruiting pedicels, large fruits, navel-like stigma, and the shiny upper surface of the leaves with prominent lateral nerves of this species indicate a close relationship with Ilex mertensii Maxim., which has thickly coriaceous leaves with obtuse apices, and palmately striate esulcate pyrenes with sublignified endocarps.

56a. Ilex uraiensis var. formosae, comb. nov.

Ilex mertensii Maxim. var. formosae Loes. in Nov. Act. Acad. Caes. Leop.Carol. Nat. Cur. 78: 338 (Monog. Aquifol. 1: 338). 1901.

Branchlets glabrous; leaves coriaceous, obovate, $2.5-4.5 \mathrm{~cm}$. long, 1.5-2.5 $\mathrm{cm}$. wide, cuneate at the base, rounded or rarely obtuse at the apex, olivaceous when dry, shiny above, the margin remotely crenulate, the midrib plane or slightly impressed above, elevated beneath, the lateral nerves 4-6 pairs, prominent on both surfaces, the reticulation of the veinlets evident on both surfaces; infructescences fasciculate, uniflorous, the fruiting pedicels 5-10 mm. long, glabrous, with 2 basal prophylla; fruit globose, 10-12 mm. in diameter, the persistent calyx inconspicuous, 1.5 $\mathrm{mm}$. in diameter, the stigma navel-like, $1.5 \mathrm{~mm}$. in diameter; pyrenes 4 , oblong in outline, obtuse at the base, obtuse and retuse at the apex, $8 \mathrm{~mm}$. long, $5 \mathrm{~mm}$. wide, irregularly striate and wrinkled, the back flattened and depressed, the endocarp stony. 
CHInA: T a iwan: S. Cape, A. Henry 938 (A, US), 1002 (IsosynTYPE of Ilex mertensii var. formosae) (A), 1251 (ISOSyntype of Ilex mertensii var. formosae) (A, NY).

The form of the leaf of this variety is like that found in Ilex mertensii Maxim., but the texture resembles that found in Ilex uraiensis. Thus superficially it may be considered as a variety of either of these two species. The large stony pyrenes of this variety, however, are typically those of Ilex uraiensis; hence it has been transferred to this species.

\section{Hlex subficoidea, sp. nov.}

Ilex cinerea sensu Groff in Lingnan Sci. Bull. 2: 63. 1930, non Champ.

Arbor; ramulis glabris; foliis coriaceis, supra nitidis, ovato- vel oblongoellipticis, $7-10 \mathrm{~cm}$. longis, $3 \mathrm{~cm}$. latis, crenatis, basi obtusis, raro rotundatis, apice acuminatis, acuminibus, 7-16 mm. longis, costa supra impressa, subtus elevata, nervis lateralibus 10-11 paribus, supra obscuris, subtus evidentibus; inflorescentiis fasciculatis, axillaribus, flores 4-meris; of 3floribus, pedunculis $1 \mathrm{~mm}$. longis, pedicellis $2 \mathrm{~mm}$. longis; calycibus 4-lobatis, ciliatis; corolla rotata, $7 \mathrm{~mm}$. diametro, petalis obovato-oblongis, $2.75 \mathrm{~mm}$. longis, sparse ciliatis, staminibus quam petalis longioribus, ovario aborto conico, apice obtuso; infructescentiis fasciculatis, pedicellis $10 \mathrm{~mm}$. longis; fructibus globosis, $10-12 \mathrm{~mm}$. diametro, tuberculatis, stigmate applanato-discoideo; pyrenis $4,8-9 \mathrm{~mm}$. longis, 5-7 mm. latis, irregulariter rugosis et caveatibus.

An evergreen tree up to $15 \mathrm{~m}$. high, with glabrous longitudinally striate branchlets, ovate- or oblong-elliptic coriaceous and glossy leaves with an abruptly acuminate apex, large $(10 \mathrm{~mm}$. in diameter) fasciculate fruits, and large woody wrinkled pyrenes.

Branchlets straight, cinereous, brunneous, or even olivaceous; third year's growth $3-4 \mathrm{~mm}$. in diameter, longitudinally striate and minutely rimulose, the lenticels lacking, the leaf-scars deltoid, ovate, not elevated; current year's growth striate, angular, 1.5-2 $\mathrm{mm}$. in diameter, glabrous, the terminal bud thinly conical, glabrescent or glabrous, the scales densely ciliate. Leaves occurring also on second year's growth, 1-2 cm. apart; stipules minute, broadly deltoid, callose; petioles 5-12 $\mathrm{mm}$. long, onefourteenth to one-seventh as long as the lamina, canaliculate above, the distal half narrowly winged by the decurrent base; lamina coriaceous, olivaceous when dry, ovate- or oblong-elliptic, 7-10 cm. long, $3 \mathrm{~cm}$. wide; obtuse at the base, seldom rounded, the apex abruptly acuminate, the acumen $7-16 \mathrm{~mm}$. long, the tip obtuse, shiny above, opaque beneath; margin undulate, inconspicuously crenate, the teeth marked with black spots; midrib impressed above, elevated beneath, the lateral nerves 10-11 pairs, obscure above, evident beneath, rather straight, curving upward and reticulate near the margin. Inflorescence fasciculate, axillary, on second year's growth; flowers 4-merous. Staminate inflorescence: individual branches of the fascicles 3 -flowered, the bracts broadly ovate, mucronate, ciliate, the basal appendages stipule-like; peduncles $1 \mathrm{~mm}$. long, the pedicels $2 \mathrm{~mm}$. long, pubescent or glabrescent; calyx patelliform, $5 \mathrm{~mm}$. 
across, the lobes glabrous, very sparsely ciliate; corolla rotate, $6 \mathrm{~mm}$. across, the petals obovate-oblong, $2.75 \mathrm{~mm}$. long, the apical half very sparsely and weakly ciliate, one-tenth connate at the base; stamens slightly longer than the petals, the anthers ovoid, $0.75 \mathrm{~mm}$. long; rudimentary ovary obtusely conical, glabrous. Pistillate flower not seen. Infructescences fasciculate, the pedicels $10 \mathrm{~mm}$. long, with 2 basal or sub-basal prophylla. Fruit globose, $10-12 \mathrm{~mm}$. in diameter, tuberculate, the persistent calyx $2.5-3 \mathrm{~mm}$. across, 4-lobed, the lobes rounded, ciliate; stigma thin-discoid, distinctly 4-lobed. Pyrenes 4, ovate-elliptic in outline, the ends pointed, 8-9 $\mathrm{mm}$. long, 5-7 mm. wide, irregularly wrinkled and pitted, the endocarp stony.

CHINA: Kiangsi: Kien-nan, S. K. Lau 3979 (type, fruits, A, US). Kwangtung: Wung-yuen, S. K. Lau 2304 (A) ; Lung-t'au Mt., CCC 12736 (US). Kwangs i: S. Nan-ning, R. C. Ching 8220 (NY). H a i nan: H. Y. Liang 63772 (NY), C. Wang 34710 (A, NY), 36535 (A).

INDO-CHINA: Tonkin, $W$. T. Tsang 26911 (A).

Ilex subficoidea is a large subtropical tree found in mixed forests south of Lat. $25^{\circ} \mathrm{N}$. The flowers are white and appear in January.

The Hainan plants have long petioles and short leaves. But these differences fall within the range of variations displayed by the plant on the mainland.

58. Ilex nuculicava, sp. nov.

Ilex cinerea Champ. var., Merr. in Lingnan Sci. Jour. 5: 115. 1928;

Masamune, F1. Kainant (Hainan) 137. 1940.

Arbor parva; ramulis pubescentibus vel glabrescentibus; foliis coriaceis, oblongo-ellipticis vel raro oblanceolatis, $8-13.5 \mathrm{~cm}$. longis, $2.2-4.5 \mathrm{~cm}$. latis, subintegris, undulatis, vel crenulatis, basi obtusis, apice breviter acuminatis, acuminibus 5-10 mm. longis, costa supra impressa, nervis lateralibus 7-8 paribus, supra obscuris, subtus evidentibus; inflorescentiis fasciculatis, axillaribus, pubescentibus; floribus 4-meris; $\hat{\delta} 3$-floribus, pedunculis $1-2 \mathrm{~mm}$. longis, pedicellis $3-4 \mathrm{~mm}$. longis, calycibus ciliatis, corolla rotata, $7-8 \mathrm{~mm}$. diametro, petalis oblongo-obovatis, $3 \mathrm{~mm}$. longis, staminibus petalis aequantibus, ovario aborto subgloboso vel ovoideo, apice obtuso; $q$ unifloribus, pedicellis $3 \mathrm{~mm}$. longis, corolla choripetala, ovario ovoideo, $2.5 \mathrm{~mm}$. longo, $2 \mathrm{~mm}$. diametro, apice truncato, stigmate discoideo; fructibus globosis, $10 \mathrm{~mm}$. diametro, stigmate umbilicato; pyrenis $4,6-7 \mathrm{~mm}$. longis, $4-4.5 \mathrm{~mm}$. latis, dorso palmatim striatis et sulcatis, lateralibus rugosis et caveatibus.

An evergreen tree up to $9 \mathrm{~m}$. high with puberulent or glabrescent branchlets, large oblong-elliptic acuminate leaves, fasciculate flowers, large globose drupes and large bony wrinkled and pitted pyrenes.

Branchlets straight, cinereous, plicate and rugose when dry; third year's growth $5 \mathrm{~mm}$. in diameter, longitudinally plicate, rimulose, the lenticels lacking, the leaf-scars semi-orbicular, not elevated, closely associated with the elevated scars of the inflorescences; second year's growth $3 \mathrm{~mm}$. in diameter; current year's growth $1.75-2 \mathrm{~mm}$. in diameter, longitudinally 
ridged, sparsely pubescent, the terminal buds conic, $3 \mathrm{~mm}$. long, the scales pubescent. Leaves occurring also on second year's growth, 2-12 mm. apart; stipules minute, often obscure; petioles slender, 9-15 mm. long, one-eleventh to one-seventh the length of the lamina, castaneous or nigrescent when dry, canaliculate, sparsely puberulent above, the distal half winged by the decurrent base, rugose beneath; lamina coriaceous, olivaceous when dry, opaque above, paler and opaque beneath, oblongelliptic or rarely oblanceolate, $8-13.5 \mathrm{~cm}$. long, $2.2-4.5 \mathrm{~cm}$. wide; base obtuse; apex short-acuminate, the acumen 5-10 mm. long; margin subentire, undulate, minutely crenate, marked with black spots; midrib impressed above, sparsely and minutely pubescent, prominent and glabrous beneath, the lateral nerves 7 or 8 pairs, straight, curved upward and loosely reticulate near the margin, obsolete above, evident or prominent beneath, the reticulation of the veinlets obscure above, lacking beneath. Inflorescences fasciculate, axillary, on second year's growth, the scales of the flowering buds persistent, reniform, acute, pubescent, $1 \mathrm{~mm}$. long, 1.5 $\mathrm{mm}$. wide; flowers 4-merous. Staminate inflorescence: individual branches of the fascicles 3 -flowered, the bracts broad-ovate, acute, pubescent, with pubescent stipule-like basal appendages, the peduncles $1-2 \mathrm{~mm}$. long, densely pubescent, the pedicels $3-4 \mathrm{~mm}$. long, pubescent, with $0-2$ basal or rarely submedian prophylla; calyx patelliform, sparsely pubescent, $2-2.5$ $\mathrm{mm}$. in diameter, 4-lobed, the lobes rounded, ciliate, $0.75 \mathrm{~mm}$. long, 1.25 $\mathrm{mm}$. wide; corolla rotate, $7-8 \mathrm{~mm}$. in diameter, the petals oblong-obovate, $3 \mathrm{~mm}$. long, $2 \mathrm{~mm}$. wide, shortly and sparsely ciliate or eciliate, lightly connate at the base; stamens equaling the petals in length, the anthers ovoid, $1.25 \mathrm{~mm}$. long; rudimentary ovary subglobose or ovoid, the apex rounded or obtuse. Pistillate inflorescences: individual branches uniflorous, the pedicels $3 \mathrm{~mm}$. long with 2 basal prophylla, the calyx and corolla as in the staminate flowers; staminode one-third the length of the petals, the sterile anthers sagittate; ovary ovoid, $2.5 \mathrm{~mm}$. long, $2 \mathrm{~mm}$. in diameter, the apical end truncate, the stigma discoid. Fruit globose, $10 \mathrm{~mm}$. in diameter, when dry cinereous and wrinkled, the pedicels 5-6 $\mathrm{mm}$. long, the persistent calyx explanate, $2.5 \mathrm{~mm}$. in diameter, pubescent and ciliate, the stigma navel-like, $3 \mathrm{~mm}$. across. Pyrenes 4 , broad-elliptic in outline, tapering at the ends, $6-7 \mathrm{~mm}$. long, $4-4.5 \mathrm{~mm}$. wide, palmately striate and sulcate on the back, wrinkled, pitted and rugose on the sides, the endocarp woody.

CHINA: Hainan: Fan-yah, N. K. Chun \& C. L. Tso, 44244 (TYPe, A: NY, US, fruit); Po-ting, F. C. How 72490 (A) ; Man-ning, F. C. How 73195 (A); Ch'ang-kiang, S. K. Lau 1714 (A, NY); Bak-sa, S. K. Lau 26006 (A), 26550 (A), 26697 (A); Five Finger Mt., F. A. McClure (CCC no. 9424) (A, NY), 9458 (A, US), 9534 (US); without precise locality, C. Wang 34741 (NY).

This species is endemic to the island of Hainan, where it grows in woods or forests at altitudes of 500-1800 m. The flowers appear in April or May. A close relative is Ilex cinerea Champ. Many herbarium sheets have 
been incorrectly so named. Ilex nuculicava resembles Ilex cinerea in having pubescent branchlets and terminal buds, and large oblanceolate or oblong-elliptic opaque leaves, but the latter can readily be distinguished by the characteristic short petiole $(2-4 \mathrm{~mm}$. long) and the twice trichotomously branched staminate inflorescences.

58a. Ilex nuculicava var. brevipedicellata, var. nov.

Arbor parva; ramulis et gemmulis terminalibus pubescentibus; foliis oblongo-ellipticis vel oblanceolatis, $7-17 \mathrm{~cm}$. longis, basi cuneatis, apice acuminatis; fructibus globosis, pedicellis $2 \mathrm{~mm}$. longis; pyrenis $4,6 \mathrm{~mm}$. longis, $5 \mathrm{~mm}$. latis, dorso rugosis et caveatibus.

CHINA: Hainan: N.K. Chun \& C. L. Tso 43859 (Type, A; US).

This variety differs from the species in having shortly pedicellate fruits. 58b. Ilex nuculicava var. glabra, var. nov.

Arbor parva; ramulis et gemmulis terminalibus glabris; foliis lanceolatis vel oblanceolatis, $8-11 \mathrm{~cm}$. longis, $2-3 \mathrm{~cm}$. latis, basi cuneatis, apice acuminatis; fructibus globosis, $9 \mathrm{~mm}$. diametro, calycibus ciliatis; pyrenis 4, 6-8 mm. longis, $5 \mathrm{~mm}$. latis, dorso rugosis et caveatibus.

CHINA: Hainan: Yai-chow, F. C. How 71094 (Type, A; NY, US).

This variety differs from the species in having glabrous buds, branchlets, and inflorescences.

58c. Ilex nuculicava var. auctumnalis, var. nov.

Arbor parva; gemmulis terminalibus pubescentibus, foliis coriaceis, supra nitidis, oblanceolatis, $6-11 \mathrm{~cm}$. longis, $2-3.5 \mathrm{~cm}$. latis, basi cuneatis, apice acuminatis; inflorescentiis fasciculatis.

CHINA: Hainan : Ling-shui, F. C. How 73800 (A); Po-ting, F. C. How 73857 (A); Yai-chow, H. Y. Liang 62751 (TYPE, A; NY).

This variety differs from the species in having smaller and narrower oblanceolate leaves, with cuneate bases, and in its late flowering season. In Hainan it flowers in the autumn, August-October. No fruiting specimens were available for this study. Additional material may prove it to be a distinct species. 


\section{$2 \mathrm{BHL}$ Biodiversity Heritage Library}

Hu, Shiu-Ying. 1949. "The genus Ilex in China, II." Journal of the Arnold Arboretum 30(4), 348-387. https://doi.org/10.5962/bhl.part.18051.

View This Item Online: $\underline{\text { https://www.biodiversitylibrary.org/item/33606 }}$

DOI: https://doi.org/10.5962/bhl.part.18051

Permalink: https://www.biodiversitylibrary.org/partpdf/18051

\section{Holding Institution}

Missouri Botanical Garden, Peter H. Raven Library

\section{Sponsored by}

Missouri Botanical Garden

\section{Copyright \& Reuse}

Copyright Status: In copyright. Digitized with the permission of the rights holder.

Rights Holder: Arnold Arboretum of Harvard University

License: http://creativecommons.org/licenses/by-nc-sa/3.0/

Rights: https://biodiversitylibrary.org/permissions

This document was created from content at the Biodiversity Heritage Library, the world's largest open access digital library for biodiversity literature and archives. Visit BHL at https://www.biodiversitylibrary.org. 